\title{
Fads and Trends in Business and Information Systems Engineering and Information Systems Research - A Comparative Literature Analysis
}

Business and information systems engineering (BISE) is currently undergoing a phase of increasing internationalization and the U.S.-based Information Systems (IS) discipline is often considered as an ideal. Using language-statistical evaluations of articles in German- and Englishspeaking journals, the authors highlight the thematic trends and differences between the BISE and the IS discipline. BISE more consistently dwells on recent developments than IS research does, but is also subject to a greater risk of placing too much emphasis on fads. BISE is topically more diverse and more specific than IS research. Buzzwords in IS usually show a higher abstraction level than in BISE articles. This may be interpreted as a reduced orientation towards practice, but may also be considered as a strength of IS research in terms of developing universal theories.

DOI 10.1007/s12599-009-0079-7

\section{The Authors}

MMag. Katharina Steininger Priv.-Doz. Mag. Dr. René Riedl o. Univ.-Prof. Mag. Dr. Friedrich Roithmayr

Johannes Kepler University of Linz Chair of Business Informatics, Information Engineering

Altenbergerstrasse 69

4040 Linz, Austria

\{katharina.steininger | rene.riedl

| friedrich.roithmayr\}@jku.at

Prof. Dr. Dr. h.c. mult. Peter Mertens University of Erlangen-Nürnberg Chair of Information Systems I

Lange Gasse 20

90403 Nuremberg, Germany

mertens@wiso.uni-erlangen.de

Received: 2007-04-29

Accepted: 2009-03-16

Accepted after three revisions

by Prof. Dr. Buhl.

This article is also available in German in print and via http://www.wirt schaftsinformatik.de Steininger K, Riedl R, Roithmayr F, Mertens P (2009) Moden und Trends in Wirtschaftsinformatik und Information Systems - Eine vergleichende Literaturanalyse. WIRTSCHAFTSINFORMATIK. doi: 10.1007/11576-009-0200-z.

\section{Introduction}

Business and information systems engineering (BISE, which is considered the English-language equivalent of the German term Wirtschaftsinformatik or WI) focuses on the investigation and development of information systems. Such information systems consist of the components human (HU), task (TA), and technology (TE) - see, for example, the remarks on the HU-TA-TE (in German: MAT) classification in Heinrich et al. (2007). Thus, BISE's research fields are explicitly defined. However, there is not always agreement on the research foci, central scientific objects, and research topics (Heilmann and Heinrich 2006; Heinzl et al. 2001; König et al. 1995; Mertens and Barbian 1999). In addition, fundamental terms are sometimes defined very inconsistently in BISE, complicating the formation of a scientific terminology, which may negatively affect scientific progress (Heinrich et al. 2007, p. 62; Mertens 2006b, p. 35).

One reason for the lack of consensus on research topics and definitions of terms could be that BISE is - compared to natural sciences, but also to established human and social sciences (e. g., psychology or sociology) - a relatively young discipline as it has existed only for a few decades (Heinrich et al. 2007). Another reason for the diversity of topics and concepts may be that information technology as a central component of BISE's research focus has been subjected to rapid change during the past decades (Fenn 1995), leading to a permanent adaptation of research topics (Lange 2005).

In 1995, Mertens presented the results of a content analysis investigating the magazine "Computerwoche" (Mertens 1995). This analysis comprises the documentation and count of catchwords from all headlines of published articles in the period from 1975 to 1994 . The resulting longitudinal data were used to draw conclusions about the historical development of topics in BISE. In 2006, the same author presented the results of a follow-up investigation ("Computerwoche"; investigation period from 1995 to 2005). The main result of both analyses is that BISE is to a high degree dominated by short-term and often fadlike topics (Mertens 2006a; 2006b).

In addition to dealing with fads, in BISE there has been a trend towards internationalization in the last few years (Frank 2003). In particular, BISE research is increasingly aligned to its Anglo-American sister discipline of Information Systems (IS). Several articles currently discuss this recent development (Becker 2008; Frank 2008; Kurbel 2008), because - although both disciplines have a similar object of study - significant differences exist with respect to the scientific objectives pursued and research methods used. While BISE is primarily design-oriented and mainly uses deductive methods, case studies, and prototyping (Wilde and Hess 2007), the IS disci- 
pline predominantly explains human behavior in the development and usage of information systems, which requires - at least according to a majority of IS representatives - the use of quantitative-empirical methods, such as surveys of experiments (Chen and Hirschheim 2004).

\section{Research questions}

The objective of the present paper is - especially in the context of the increasing internationalization in $\mathrm{BISE}^{1}$ - to investigate the usage of terminology and the development of research topics in BISE and IS research. The present study also differs from the previous two studies by Mertens (2006a; 2006b) in so far as we are trying to revoke some limitations. In particular, we aim at increasing the findings' validity through a wider range of investigated journals. Furthermore, specific statistical definitions of course patterns are supposed to increase the investigation's transparency and objectivity.

The four key research questions are:

1. Which terms dominate BISE and IS research in the period from 1994 to 2007?

2. Which developmental patterns are shown by the topics in BISE and IS?

3. Which developmental patterns are shown by the individual components and the dyads of the HU-TA-TE classification in BISE and IS research?

4. Which implications arise from the findings on the questions (1), (2), and (3) for BISE and IS research?

Question (1) is of interest because a precise terminology is essential for the continuous existence and development of a scientific discipline (Chmielewicz 1994, pp. 49 ff; Wohlgenannt 1969, p. 102 f). For BISE, this is important as it is subject to the risk of (unreflectively) adopting Anglicisms as well as promotional terms from business practice. The comparison of the prevailing terminology of BISE with that of IS research is of high relevance as numerous studies show that both disciplines are characterized by their focus on different research objectives (design vs. behavior), epistemological position (interpretivism

\footnotetext{
Since 2005, Ulrich Frank, University of Duisburg-Essen, has been running a research project funded by the DFG (Deutsche Forschungsgemeinschaft) with the title "International comparison of research programs in BISE and IS". The DFG funding of this project accounts for the significance of internationalization in BISE.
}

vs. positivism), and research methods (modeling as well as development and testing of prototypes vs. surveys and experiments) (Chen and Hirschheim 2004; Heinzl et al. 2001; König et al. 1995; 1996; Mingers 2003; Schauer and Frank 2007; Schauer and Schauer 2008; Vessey et al. 2002; Wilde and Hess 2007). The analysis of predominant terms is also a precondition to examine the extent of the diversity of terms and topics in BISE and IS as well as their degree of abstraction. On the one hand, we will discuss the diversity of topics in order to contribute to the longstanding discourse on the advantages and disadvantages of a distinct topical diversity (e. g., Benbasat and Weber 1996; Krcmar 1999). On the other hand, dealing with the abstraction level creates insights into the theory and practice focus of a discipline, since we assume that a theory focus corresponds with a high degree of abstraction while a practical focus goes along with a high degree of concretization. Question (2) seems important as in the two earlier studies only the magazine "Computerwoche" was analyzed. Therefore, the question arises whether the analysis of scientific journals leads to an equal dominance of fads. Question (3) is of interest because both BISE and IS have a similar object of study (HU-TA-TE) (Heinrich et al. 2007; Laudon and Laudon 2002). We will examine how the topical discussion of the three components $\mathrm{HU}$, TA, and TE and their dyads HU-TA, HUTE, and TA-TE has changed in BISE and IS research. On the basis of this common theoretical framework, this will reveal the differences and similarities of the two disciplines on an abstract level over time. Finally, a comparison of the developmental patterns of prevailing topics in BISE and IS is important to obtain evidence for the future development of both disciplines (question 4).

\section{Paper structure}

The remainder of this article is structured as follows: We begin with the presentation of the chosen research method; the section is divided into data collection and analysis (section 4). Then, in section 5 , we describe five idealized course patterns illustrating the different developmental patterns of topics (trends, negative trends, fads, recurring fads, and oscillating topics). In section 6 , we present the results of the research questions (1), (2), and (3). In section 7, we discuss possible implications of the results for BISE and IS, and thus address research question (4). In section 8 , we explain the limitations of our analysis. In section 9, we provide a conclusion and an outlook on future research.

\section{Research method}

To answer the research questions we conducted a document analysis which has the general aim to draw conclusions about the content of a document (Lisch and Kriz 1978; Mayring 2003; Krippendorff 2004). The document analysis is therefore appropriate to explore the terms mentioned in the BISE and IS literature as well as the developmental patterns of topics (see also two recently published articles by Chen et al. 2008 and Sidorova et al. 2008). The units of analysis in the present study are words (e. g., outsourcing) and word combinations (e. g., enterprise resource planning) (Diekmann 2006, pp. $488 \mathrm{f}$; Hugl 1995, p. 30). The analysis is based on the assumption that the frequency of mentioning a term allows for inferring its importance in scientific research at a certain time. If, for example, the term outsourcing is mentioned many times within one year, it is assumed that the issue of outsourcing is of high importance in research.

\subsection{Data collection}

In order to be able to draw conclusions about terms and topics in BISE and IS we investigated a total of eight journals. We chose three BISE journals (WIRTSCHAFTSINFORMATIK, HMD - Praxis der Wirtschaftsinformatik, and Information Management \& Consulting) as well as five IS journals (MIS Quarterly, Information Systems Research, Information Systems Journal, Information \& Management, and Communications of the ACM). ${ }^{2}$ (The journal WIRTSCHAFTSINFOR$M A T I K$ infrequently published articles in English during the investigation period which are considered as BISE articles in the present study.)

\footnotetext{
2 A list of ranking studies can be accessed at the website of the Association for Information Systems at http://home.aisnet.org/. Moreover we refer to the BISE orientation list which has been agreed upon during the Multikonferenz Wirtschaftsinformatik on 2008-02-27 (cf. WIRTSCHAFTSINFORMATIK 50(2):155-163).
} 


\section{Electrifying, dynamic, innovative. IT is my world!}

Patrick Rumpel, Allianz Deutschland AG, IT Manager

Handling complex tasks with the most modern technology. Allianz IT means excitement and challenge. Every day, everywhere in Germany. Together with our colleagues, we are on a constant search for the optimum solution.

What are you searching for? 


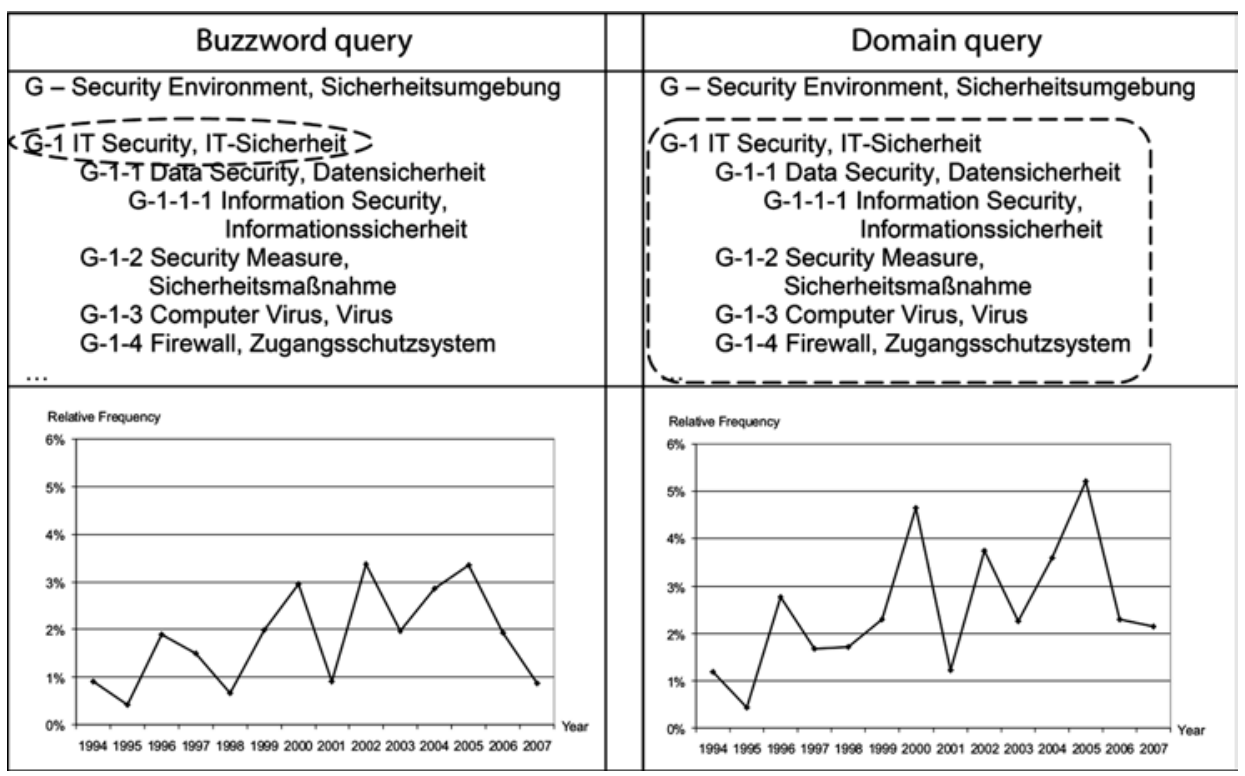

Fig. 1 Buzzword and domain query based on the example IT Security (BISE and IS)
The investigation period ranged from August 1994 to December 2007. Non-relevant categories such as recensions and book reviews have been excluded from the analysis. The search led to the identification of 2,564 BISE articles and 5,647 IS articles. For each paper we identified terms from the (i) title, (ii) summary or abstract, and (iii) keywords, which were stored together with each article's descriptive data (author, title, journal, month and year of publication) as so called catchwords in a database. The determination of the topical orientation of a paper on the basis of its title, abstract, and keywords is a widely practiced technique leading to reliable research results (Alavi and Carlson 1992; Farhoomand and Drury 1999; Palvia et al. 1996; Swanson and Ramiller 1993). One reason for the choice of our research design was that the alternative approach - to read the full text and to subsequently define the topic of the article interpretatively - may be less comprehensible to a third person. After the documentation of the data we conducted an adjustment of the catchwords to unify different spellings (e. g., singular/plural, hyphens, upper and lower case). In BISE, we documented 10,488 catchwords for the three journals and 11,473 in the five IS journals (after adjustment).

\subsection{Data analysis}

A central component of content analyses is the assignment of words and/or word combinations to categories (Mayring 2003). In BISE (Herzwurm and Stelzer
2008; Lange 2005) and in IS (Barki et al. 1988 ; 1993) there are category systems for classifying scientific papers. The application of these classification schemes in the context of the present study turned out to be inappropriate since they show a high degree of abstraction and/or are available only in one language. In order to reliably answer the research questions (1) and (2), however, we needed a less abstract classification scheme in German and English. Therefore, we inductively developed a hierarchical category system from the documented catchwords (Atteslander 2006; Bortz and Döring 2006; Hugl 1995; Mayring 2003). The category system was developed by the first author of this paper together with six BISE diploma candidates (Steininger and Riedl 2009).

We summarized the catchwords together with their acronyms, synonyms, and translations to buzzwords, which form a layer in the hierarchy (e. g., "G-1 IT Security, IT-Sicherheit" in Fig. 1, lefthand side). The hierarchical structure of the classification scheme is essential because then both the analysis of topics as well as of individual buzzwords is possible. Buzzword queries in our database aim at making statements about the frequency of terms (including their acronyms, synonyms, and translations) (e. g., buzzword query IT-Security: G-1 in Fig. 1, left-hand side). Buzzword queries therefore enable the answering of research question (1). Domain queries, in contrast, aim at revealing the development of an entire topical area (e. g., domain query IT-Security: G-1 + G-1-1 + G-1-1-1 + G-1-2 + G-1-3 + G-
1-4 in Fig. 1, right-hand side). Therefore, domain queries allow answering research question (2).

In the lower part of Fig. 1 the temporal development of the buzzword IT-Sicherheit/IT Security as well as of the whole topical area of IT Security is represented based on all eight journals. We plotted the relative proportion of articles which contain a particular catchword against the $y$-axis (referred to as "relative frequency"). For instance, in 2004 the buzzword IT Security appears in almost three percent of all articles investigated (Fig. 1, left-hand side).

To answer research question (3) we categorized the 100 most frequently mentioned terms - based on buzzword queries - with respect to their topical focus into the classes HU, TA, and TE and their dyads HU-TA, HU-TE and TA-TE. We excluded 13 terms referring to research methods (e. g., case study in BISE or structural equation modeling in IS) and discipline names (such as management science or computer science in IS). The classification was carried out by the first author and the second author of this paper who independently conducted the classification of the remaining 187 terms into the six classes. In 20 cases there was no consensus. To determine the inter-rater reliability we used Cohen's Kappa coefficient (Cohen 1960). This value indicates the degree of consistency of coding between two persons, while the possibility of random match is already taken into account. According to Landis and Koch (1977) values for the Cohen's Kappa coefficients are "substantial" between 0.61 and 0.80 and 
Fig. 2 Idealized course patterns

values above are "almost perfect". The value of Cohen's Kappa coefficient for the 187 classified keywords was $0.89\left[p_{o}=1\right.$ (20/187) and $p_{c}=1 / 36$; see Cohen 1960, p. 40] - therefore, the result of the coding is highly reliable.

\section{Ideal course patterns}

Research Question (2) of the present study is: Which developmental patterns are shown by topics in BISE and IS? Drawing upon the study by Mertens (1995), we therefore defined idealized course patterns of (i) trends, (ii) negative trends, (iii) fads, (iv) recurring fads, and (v) oscillating topics.

The verification of whether a topic fits an idealized course pattern has been conducted on the basis of standardized scores (so-called $z$-values). Such a standardization represents a linear transformation where the values obtained have a mean of $\overline{\mathrm{x}}=0$ and standard deviation $s=1$ (Bortz 2005 , p. 45). The standardization was performed to make possible the comparison of development patterns which are based on very different relative frequencies of topical areas. These relative frequencies of topics in the years investigated range from 0 percent (e. g., $X M L$ before the year 1999 in the three BISE journals) to 32 percent (technology in 2001 in the five IS journals).

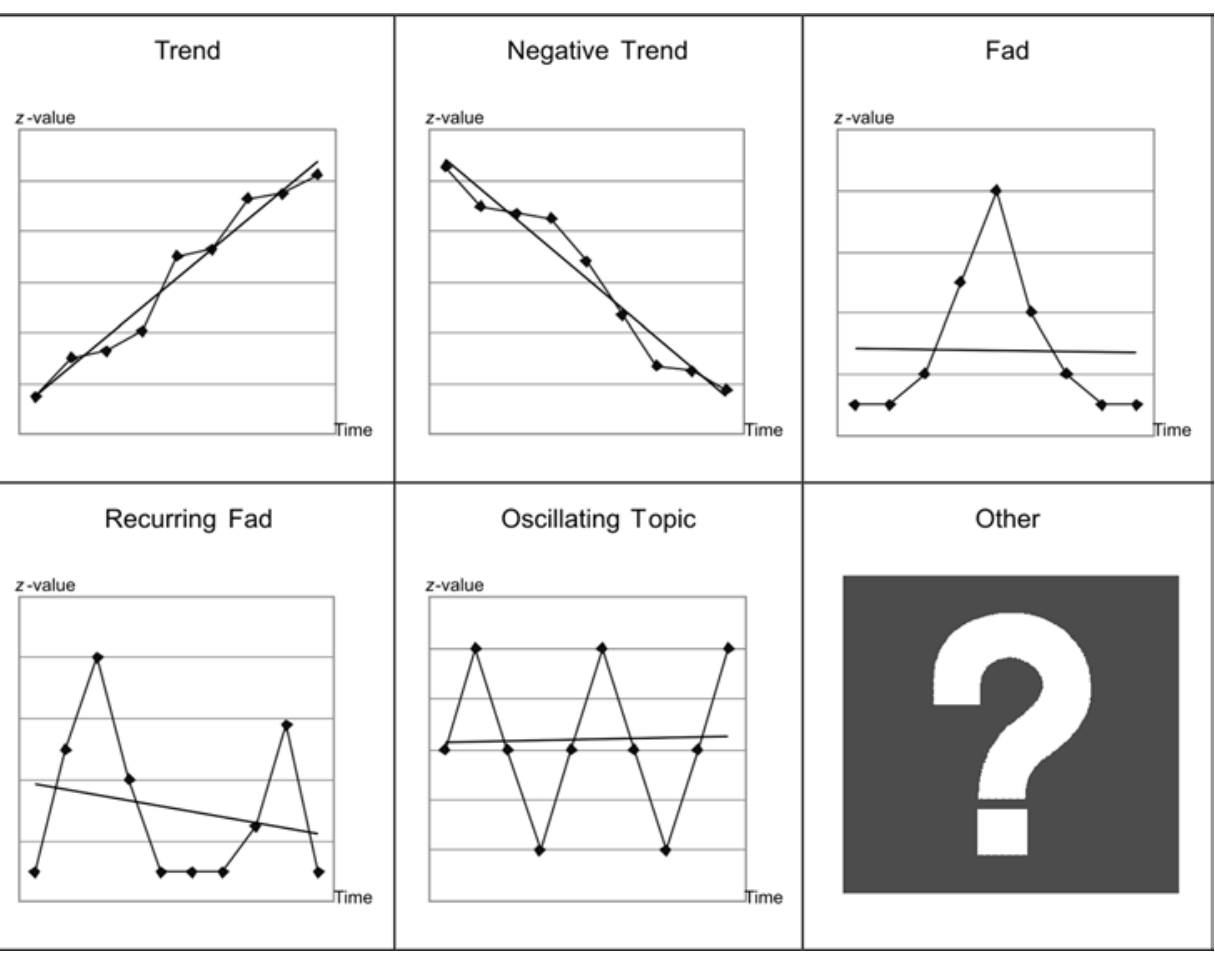

Fig. 2 shows idealized course patterns of (i) trends, (ii) negative trends, (iii) fads, (iv) recurring fads, and (v) oscillating topics including the linear regression line $f(x)=k x+d$, where $k$ represents the slope of the curve and $d$ expresses the $y$-intercept. In the following, we define formal criteria for assigning specific developmental patterns of the topics to the idealized course patterns. If a developmental pattern can be assigned to none of the defined idealized curves (i) to (v), we classified it into the group "Other".

For the definition of formal criteria, we refer to the coefficient of determination $R^{2}$ of the linear regression line $\left(0 \leq R^{2} \leq 1\right)$. This measure indicates the strength of the linear relationship between $x$ (time) and $y$ (standardized relative share of articles in which a particular catchword appears). $R^{2}$ of 0.7 , for example, expresses that 70 percent of the variance of $y$ can be described by the linear relationship between $x$ and $y$. The remaining 30 percent of the variance cannot be explained by the linear relationship. In other words: $R^{2}$ is a measure which indicates how well the linear regression line is adjusted to the data points (Bortz 2005 , pp. 209 f).

\subsection{Trend}

We defined the formal criteria for a developmental pattern to be categorized as a trend as follows: (i) $k>0$ (to express the increase of the topic's importance); (ii) no decrease in the topic's relevancy within more than two consecutive years; and (iii) $R^{2}>0.5$.

Fig. 3 shows the development of the topic trust as an example for a trend from IS research. The three criteria are fulfilled, because (i) $k=0.1774$; (ii) the topic's relevancy in the years 1997, 1999, 2001, 2002, 2005, and 2007 declines compared to the respective previous year, but no decline is identified in more than two consecutive years; (iii) $R^{2}=0.5111$.

\subsection{Negative trend}

The formal criteria for a developmental pattern to be considered as a negative trend are defined as follows: (i) $k<0$ (to express the decline in the topic's importance); (ii) no increase in the topic's relevancy within more than two consecutive years; and (iii) $R^{2}>0.5$.

Fig. 4 shows an example for a negative trend from BISE research, namely the topic database. The three criteria are met again, because (i) $k=-0.1841$; (ii) the topic's relevancy increases in the years 1996, 1997, 2000, and 2002 compared to the respective previous year, but no increase is identified in more than two consecutive years; (iii) $R^{2}=0.5510$. Claver et al. (2000, p. 184) found that the topic database is a negative trend in IS, too (period from 1981 to 1997). 
z-value

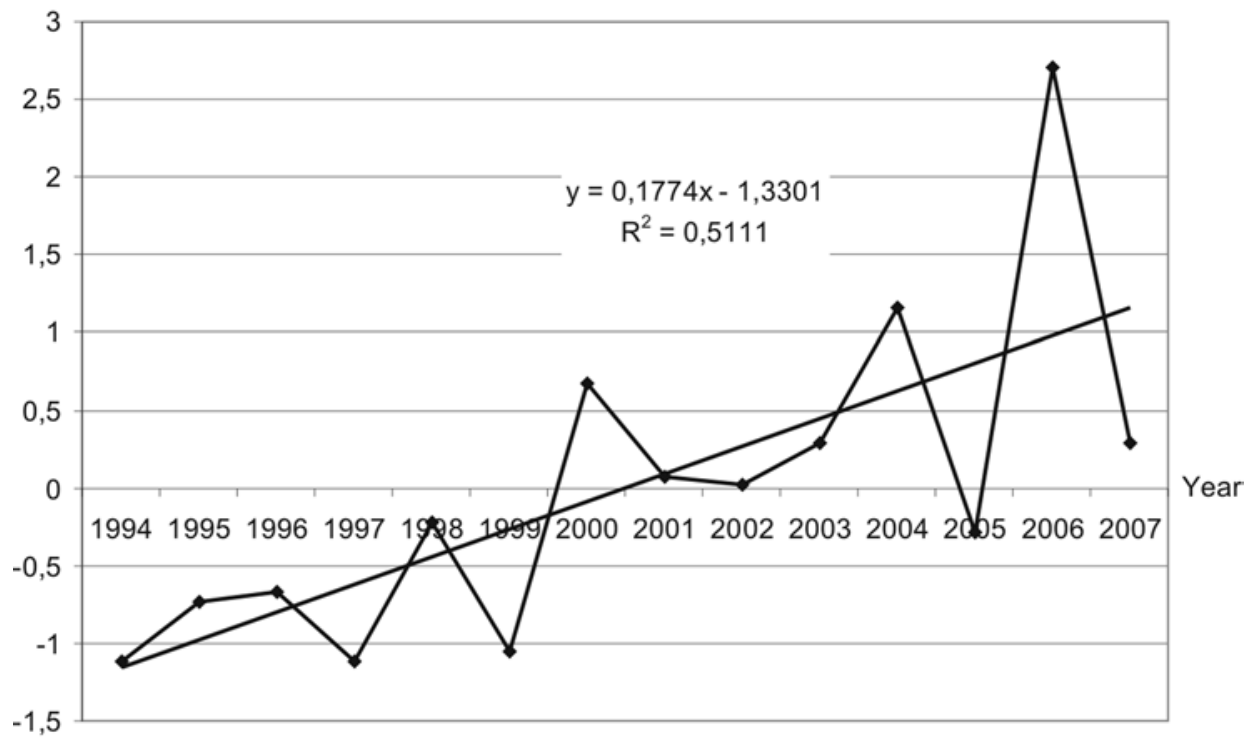

Fig. 3 Course of an IS trend (trust)

z-value

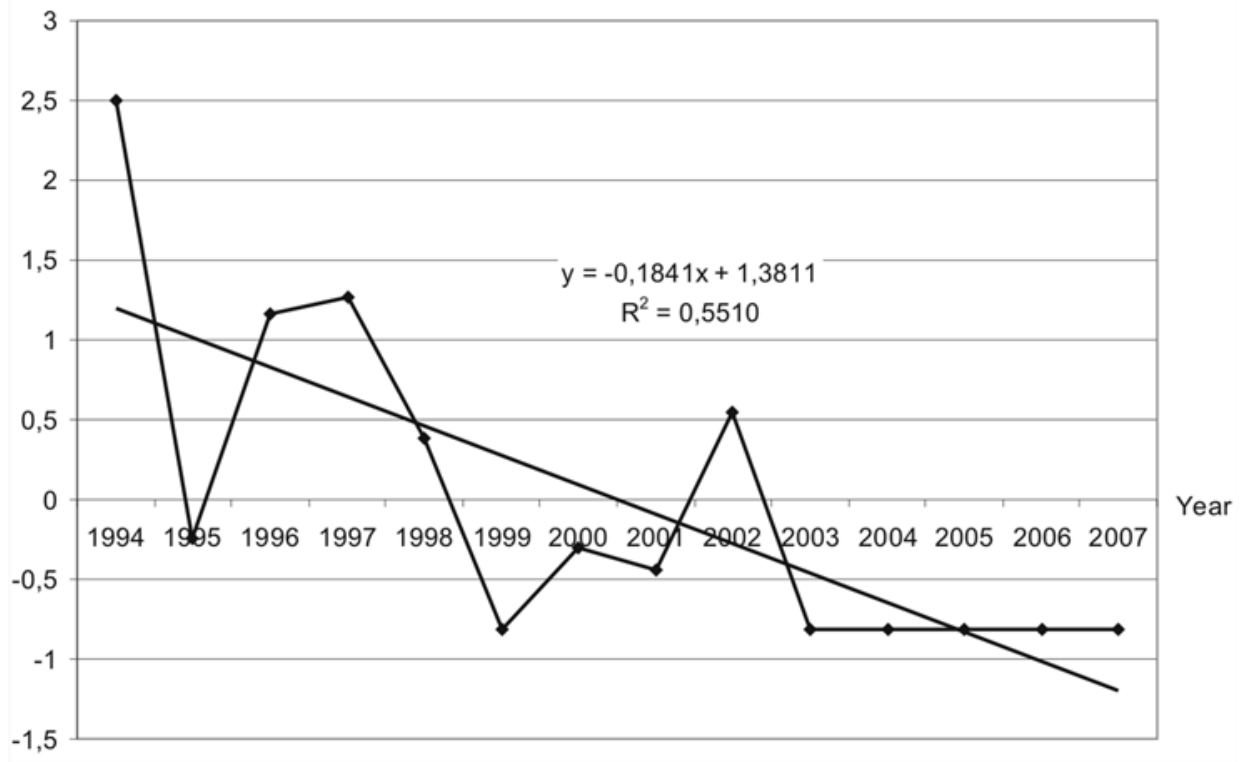

Fig. 4 Course of a BISE negative trend (database)

\subsection{Fad}

We defined the formal criteria for a developmental pattern to be classified as a fad as follows: (i) two consecutive data points with $z$-value $_{t 0} \geq 1.5$ and $z$-value trl $_{t+1} \geq 0.5$ (this expresses the topic's summit); (ii) for a subsequent data point a $z$-value $<0.5$ within a maximum of three years after the topic's summit (decline of the fad); and (iii) $R^{2} \leq 0.5$.

Fig. 5 shows an example for a fad from BISE research, the topic e-commerce. The three criteria are met because (i) in 2001, the $z$-value of 2.2 is higher than 1.5 , and in 2000 , the $z$-value of 1.5 is higher than 0.5 (or in 2002, the $z$-value of 0.6 is also higher than 0.5); (ii) already in 2003, the $z$-value of -1.0 is lower than 0.5 ; (iii) $R^{2}=0.0112$.

\subsection{Recurring fad}

We defined the formal criteria for a developmental pattern to be considered as a recurring fad as follows: (i) two consecutive data points with $z$-value to $_{0} \geq 1.5$ and $z$-value $_{ \pm 1} \geq 0.5$ (summit of the topic); (ii) for a subsequent data point a $z$-value $<0.5$ within a maximum of three years after the summit of the topic (decline of the fad); (iii) at least one more data point that does not occur during the topic's summit for which the $z$-value $\geq 0.5$ (further summit of the issue); and (iv) $R^{2} \leq 0.5$. It should be noted that recurring fads may have a rising ( $\mathrm{k}>0$, see Fig. 6) and falling ( $<<0$, see Fig. 2$)$ tendency.

Fig. 6 shows the development of mobile commerce as an example for a recurring fad from BISE research. The four criteria are met because (i) in 2001, the $z$-value of 2.7 is higher than 1.5 , and in 2000 , the $z$ value of 1.4 is higher than 0.5 ; (ii) in 2002 , the $z$-value of 0.1 is lower than 0.5 ; (iii) in 2006, a data point outside the summit exists whose $z$-value of 0.9 is higher than 0.5 ; (iv) $R^{2}=0.0743$. 
Fig. 5 Course of a BISE fad (e-commerce)

Fig. 6 Course of a recurring fad in BISE (mobile commerce)

\subsection{Oscillating topic}

Regarding the formal criteria for the classification of a developmental pattern as an oscillating topic, we determined the following definition: (i) at least two nonconsecutive data points with a $z$-value $>0.8$ and $z$-value $<-0.8$, respectively (significant outliers, upwards or downwards); (ii) $-0.1 \leq k \leq 0.1$ (stable long-term importance of the topic); (iii) $R^{2} \leq 0.5$; and (iv) none of the significant upwards outliers meets the formal criteria (i) and (ii) of a fad.

Fig. 7 shows an example for an oscillating topic from IS research, which is organizational learning. The four criteria are met because (i) in the years 1994, 1998, and 2001 significant upwards outliers exist

z-value
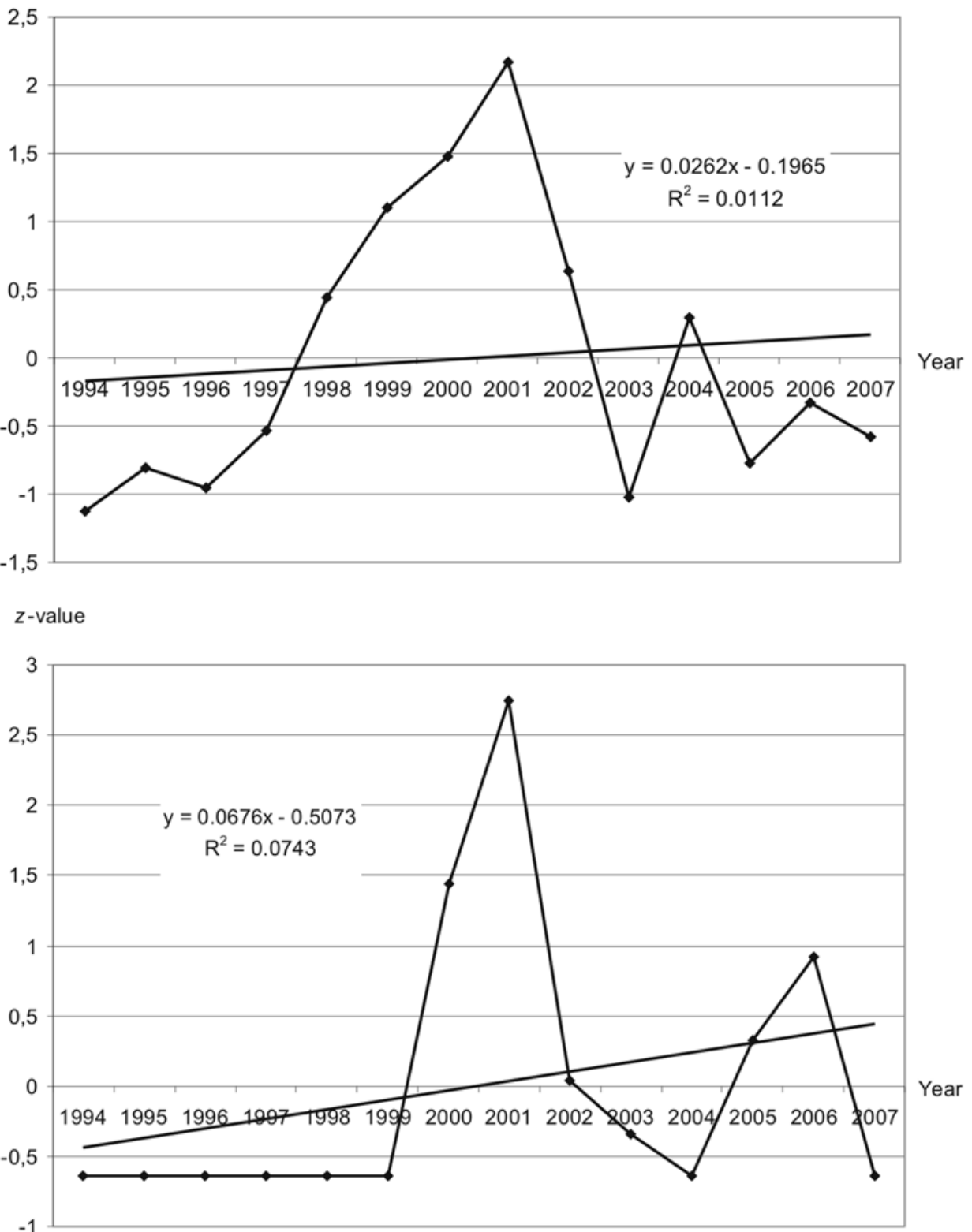

with $z$-values higher than 0.8 , and in the years 1995, 2002, and 2006 those downwards exist with $\mathrm{z}$-values lower than -0.8 ; (ii) $k=-0.0851$; (iii) $R^{2}=0.1178$; (iv) none of the significant outliers in the years 1994, 1998, and 2001 fulfills the criterion (i) of a fad ( $z$-value to $\geq 1.5$ and $z$-value $_{t \pm 1} \geq 0.5$ ).

\section{Results}

\subsection{Which terms dominate BISE and IS?}

Tab. 1 lists the dominant buzzwords of BISE and IS (top-50 ranks). ${ }^{3}$ First, we found that

Research methods and names of disciplines
which initially had been among the top-50 rank which initially had been among the top- 50 ranks
had been deleted from the list and terms from ten of the 50 most frequently mentioned buzzwords from BISE and IS occur in both language areas (those marked with an asterisk $\left\langle^{*}\right\rangle$ ): $e$-commerce, electronic data interchange (EDI), enterprise resource planning (ERP), information management (IM, Informationsmanagement), information technology (IT, Informationstechnologie), Internet, IT Security (IT-Sicherheit), outsourcing, software development (Software-

the subsequent ranks have been included in the top-50 ranks. In BISE the following terms have been deleted: Empirische Untersuchung / empirical study (rank: 46); in IS the following terms have been deleted: information systems (rank: 10), information science (rank: 16), case study (rank:

18), computer science (rank: 19), research (rank: 21), empirical study (rank: 36), computer simulation (rank: 46), management science (rank: 49). 
z-value

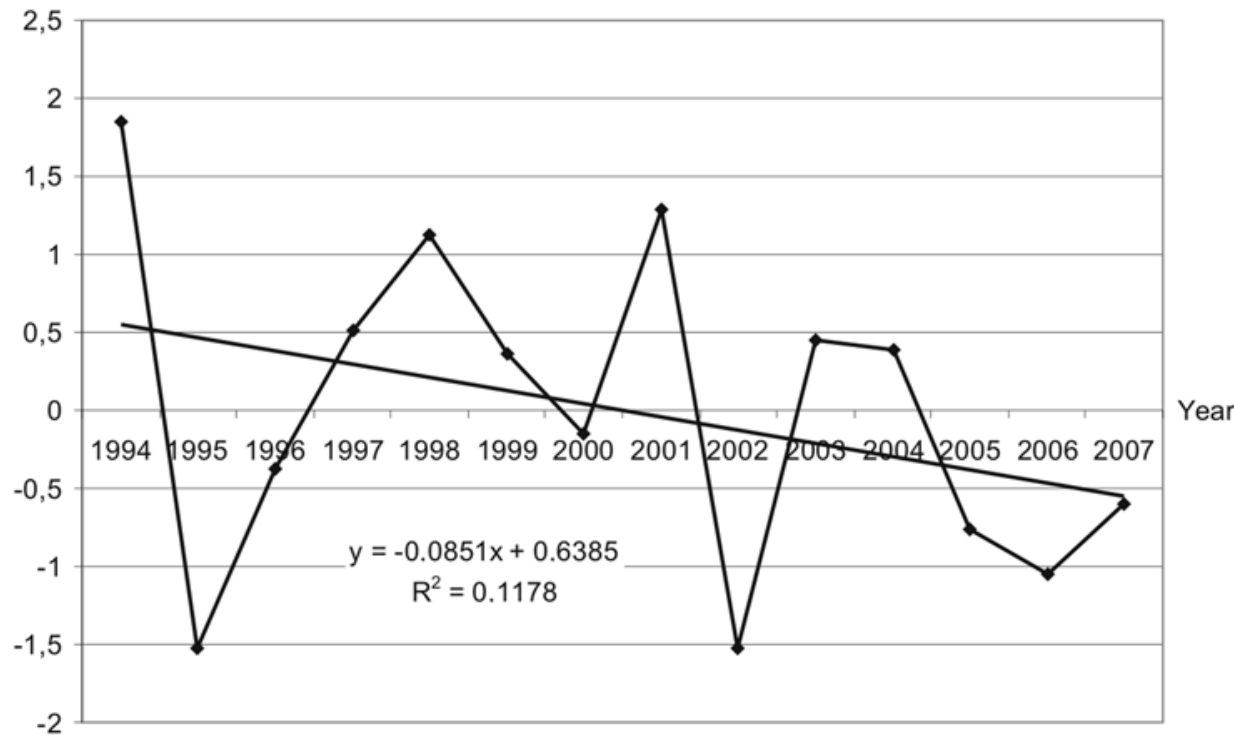

Fig. 7 Course of an oscillating topic in IS (organizational learning)
Entwicklung) and knowledge management (Wissensmanagement). One conclusion from this result is that there is a common thematic basis between BISE and IS.

Another result is that the buzzwords of IS tend to have a higher level of abstraction than those of BISE. Therefore, in BISE we can find multiple terms with a low level of abstraction (e. g., XML, ITIL, or Balanced Scorecard). In IS, however, terms at a very high level of abstraction dominate (e. g., computer, software, or technology), and this finding is in line with results of a content analysis about the "Intellectual Core of the IS Discipline" (Sidorova et al. 2008). The result is also in line with the scientific objectives of BISE and IS. While BISE researchers focus on design objectives (i. e., engineering), which generally goes along with the precise treatment of a topic, IS researchers concentrate on theoretical objectives (i. e., cause-effect relationships), which results in the development of theories; and this may require an abstraction from concrete problems and solutions (Frank et al. 2008; Heinrich et al. 2007, p. 343).

As our results also show, the relative frequencies of the top-50 buzzwords of IS are significantly higher than those of BISE (Tab. 1). For example, in BISE the topic with the highest frequency, namely Internet, can be found in 4.26 percent of all surveyed articles, while the top term of IS, information technology (IT), appears in 19.66 percent of the papers. Therefore, one conclusion is that the central terms and concepts of IS research are used at a larger extent in the literature than in BISE. The consistent use of the central terms and concepts is a prerequisite for the establishment of a cumulative research tradition (Keen 1980, p. 14).

Tab. 1 also shows that 26 out of the 50 most frequently mentioned buzzwords in BISE are Anglicisms (terms consisting of a German and an English-speaking part, for example Software-Entwicklung, were not included as Anglicism). This corresponds to an Anglicism's rate of 52 percent. When interpreting this number, it should be considered that for some Anglicisms German equivalents do not exist (e. g., Internet).

Among the 50 most frequently mentioned buzzwords of BISE there is a variety of terms that can be attributed to information management (e.g., knowledge management, business process management, ITIL, change management) and architecture and modeling (business process modeling, service-oriented architecture, reference model, process model) (Heinrich 2002; Krcmar 2006). Therefore, our results replicate the findings of existing content analyses in BISE research (e. g., Heidecke et al. 2005; Herzwurm and Stelzer 2008).

\subsection{Which developmental patterns are shown by the topics in BISE and IS?}

On the basis of domain queries (see Fig. 1) we analyzed the developmental patterns of the top-50 buzzwords in the period from 1994 to 2007. Then, we compared the developmental patterns with the formal criteria of the five idealized course pat- terns to determine the number of trends, negative trends, fads, recurring fads, oscillating topics, and other patterns. Tab. 1 indicates which keyword corresponds to which idealized course pattern. Fig. 8 shows the results of the analysis in an aggregated form.

Among the top-50 buzzwords in BISE, we could identify one trend only, which is business intelligence (see Fig. 8 and the remarks in section 8 ). The result of the present study thus replicates the findings of an investigation by Heilmann and Heinrich (2006, p. 106), who noted that the scientific objects in BISE hardly contain trends. In IS research, there is also only one trend, which is trust. Sidorova et al. (2008) also identified trust as a central topic in IS research (period from 2002 to 2006). Considering that (i) in 2008 there has been a special focus on "Trust in Online Environments" in the Journal of Management Information Systems and (ii) at the beginning of 2009 a call for papers at MIS Quarterly deals with the issue of "Novel Perspectives on Trust in Information Systems", it is likely that the research topic of trust will have great importance in the next years, too.

Both in BISE and IS the number of negative trends is low ( 6 and 10 percent, respectively). The percentage of fads in BISE is 28 percent. Among the BISE fads there are topics such as e-commerce, e-business, $X M L$, multimedia, and CRM. In IS, however, no fad could be identified. In this context, the results of a recently published interview study by Frank et al. (2008) are 


\section{The new Commerzbank:}

\section{More partnership,}

\section{more performance, more bank.}

Commerzbank - a strong partner for Germany.
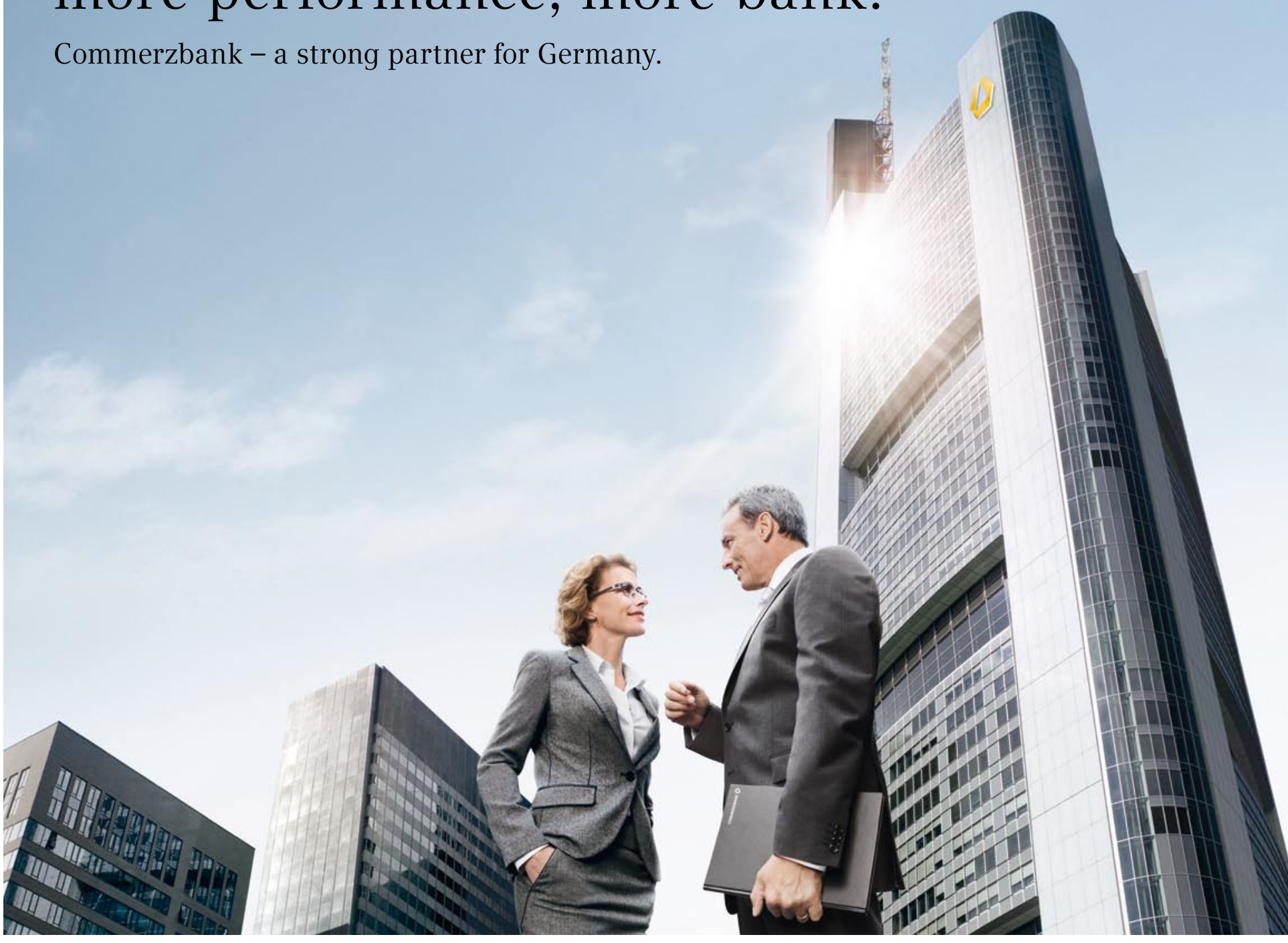

The new Commerzbank unites the strengths of Commerzbank and Dresdner Bank. As the leading bank for retail and corporate clients in Germany, we combine strong local links and a long tradition with the end-to-end expertise and power of an international network. In this way, we live our core values of partnership and performance: in our dealings with clients, investors and employees, and in providing outstanding quality and service. This makes us a reliable, strong long-term partner Germany's bank of choice. www.commerzbank.com 


\begin{tabular}{|c|c|c|c|c|c|c|c|c|}
\hline Anglicism & BISE & Frequency & Course pattern & & IS & Frequency & Course pattern & \\
\hline • & internet* & $4,26 \%$ & Oscillating topic & $\boldsymbol{\nabla}$ & $\begin{array}{l}\text { Information } \\
\text { Technology (IT)* }\end{array}$ & $19,66 \%$ & Other & $\boldsymbol{\nabla}$ \\
\hline \multirow[t]{2}{*}{ • } & e-commerce* & $2,65 \%$ & Fad & $\boldsymbol{\nabla}$ & $\begin{array}{l}\text { Information } \\
\text { Management (IM)* }\end{array}$ & $13,18 \%$ & Recurring fad & $\boldsymbol{\nabla}$ \\
\hline & $\begin{array}{l}\text { knowledge management* } \\
\text { [Wissensmanagement] }\end{array}$ & $2,53 \%$ & Fad & $\Delta$ & internet* & $7,02 \%$ & Recurring fad & $\Delta$ \\
\hline • & outsourcing* & $2,39 \%$ & Other & & information resources & $6,03 \%$ & Oscillating topic & \\
\hline • & $\begin{array}{l}\text { Enterprise Resource } \\
\text { Planning (ERP)* }\end{array}$ & $2,25 \%$ & Recurring fad & & $\begin{array}{l}\text { Management Information } \\
\text { Systems (MIS) }\end{array}$ & $5,94 \%$ & Negative trend & \\
\hline \multirow[t]{4}{*}{ - } & $\begin{array}{l}\text { Supply Chain } \\
\text { Management (SCM) }\end{array}$ & $2,13 \%$ & Oscillating topic & $\Delta$ & e-commerce* & $5,88 \%$ & Recurring fad & $\Delta$ \\
\hline & $\begin{array}{l}\text { business process } \\
\text { [Geschäftsprozess] }\end{array}$ & $2,08 \%$ & Negative trend & & computer & $5,65 \%$ & Negative trend & \\
\hline & IT security* [IT-Sicherheit] & $1,96 \%$ & Other & & software & $5,45 \%$ & Oscillating topic & \\
\hline & $\begin{array}{l}\text { process modeling } \\
\text { [Prozess-Modellierung] }\end{array}$ & $1,85 \%$ & Fad & & decision making & $4,07 \%$ & Negative trend & \\
\hline • & data warehousing & $1,53 \%$ & Recurring fad & $\Delta$ & knowledge management* & $3,36 \%$ & Recurring fad & $\Delta$ \\
\hline \multirow[t]{5}{*}{ • } & e-business & $1,48 \%$ & Fad & & $\begin{array}{l}\text { information storage } \\
\text { \& retrieval system }\end{array}$ & $3,30 \%$ & Oscillating topic & \\
\hline & $\begin{array}{l}\text { process management } \\
\text { [Prozessmanagement] }\end{array}$ & $1,47 \%$ & Fad & $\boldsymbol{\nabla}$ & system development & $3,24 \%$ & Recurring fad & $\boldsymbol{\nabla}$ \\
\hline & $\begin{array}{l}\text { Information } \\
\text { Management (IM)* }\end{array}$ & $1,45 \%$ & Recurring fad & $\Delta$ & software development ${ }^{*}$ & $3,00 \%$ & Recurring fad & $\Delta$ \\
\hline & $\begin{array}{l}\text { service oriented architecture } \\
\text { [Serviceorientierte } \\
\text { Architektur] }\end{array}$ & $1,35 \%$ & Other & $\boldsymbol{\nabla}$ & technology & $2,85 \%$ & Other & $\boldsymbol{\nabla}$ \\
\hline & $\begin{array}{l}\text { software development* } \\
\text { [Software-Entwicklung] }\end{array}$ & $1,32 \%$ & Other & $\boldsymbol{\nabla}$ & technical innovations & $2,77 \%$ & Recurring fad & $\boldsymbol{\nabla}$ \\
\hline \multirow[t]{2}{*}{ • } & $\begin{array}{l}\text { Extensible Markup } \\
\text { Language (XML) }\end{array}$ & $1,31 \%$ & Fad & $\boldsymbol{\nabla}$ & system design & $2,60 \%$ & Other & $\boldsymbol{\nabla}$ \\
\hline & $\begin{array}{l}\text { project management } \\
\text { [Projektmanagement] }\end{array}$ & $1,19 \%$ & Other & & decision support system & $2,38 \%$ & Negative trend & \\
\hline - & web service & $1,18 \%$ & Other & & management & $2,30 \%$ & Oscillating topic & \\
\hline \multirow[t]{2}{*}{ - } & e-learning & $1,16 \%$ & Oscillating topic & $\boldsymbol{\nabla}$ & electronic data processing & $2,18 \%$ & Other & $\boldsymbol{\nabla}$ \\
\hline & $\begin{array}{l}\text { reference model } \\
\text { [Referenzmodell] }\end{array}$ & $1,16 \%$ & Recurring fad & & business enterprise & $2,17 \%$ & Oscillating topic & \\
\hline • & workflow management & $1,16 \%$ & Negative trend & & organizational change & $2,08 \%$ & Oscillating topic & \\
\hline \multirow[t]{2}{*}{ • } & business intelligence & $1,14 \%$ & Trend & $\Delta$ & $\begin{array}{l}\text { Technology Acceptance } \\
\text { Model (TAM) }\end{array}$ & $1,96 \%$ & Recurring fad & $\Delta$ \\
\hline & $\begin{array}{l}\text { process improvement } \\
\text { [Prozessverbesserung] }\end{array}$ & $1,11 \%$ & Oscillating topic & $\boldsymbol{\nabla}$ & computer network & $1,96 \%$ & Recurring fad & $\boldsymbol{\nabla}$ \\
\hline \multirow[t]{4}{*}{ - } & e-market & $1,06 \%$ & Recurring fad & & trust & $1,80 \%$ & Trend & \\
\hline & $\begin{array}{l}\text { standard software } \\
\text { [Standardsoftware] }\end{array}$ & $1,04 \%$ & Recurring fad & $\Delta$ & IT security* & $1,75 \%$ & Recurring fad & $\Delta$ \\
\hline & multimedia & $0,99 \%$ & Fad & $\boldsymbol{\nabla}$ & industrial management & $1,71 \%$ & Recurring fad & $\boldsymbol{\nabla}$ \\
\hline & $\begin{array}{l}\text { Information Technology (IT)* } \\
\text { [Informationstechnologie] }\end{array}$ & $0,95 \%$ & Other & $\Delta$ & outsourcing* & $1,68 \%$ & Recurring fad & $\Delta$ \\
\hline - & mobile commerce & $0,94 \%$ & Recurring fad & $\boldsymbol{\nabla}$ & high technology & $1,67 \%$ & Recurring fad & $\boldsymbol{\nabla}$ \\
\hline - & IT Infrastructure Library (ITIL) & $0,92 \%$ & Other & & organization & $1,58 \%$ & Oscillating topic & \\
\hline \multirow[t]{2}{*}{ - } & $\begin{array}{l}\text { Electronic Data } \\
\text { Interchange (EDI)* }\end{array}$ & $0,89 \%$ & Recurring fad & & expert system & $1,58 \%$ & Negative trend & \\
\hline & $\begin{array}{l}\text { business process reenginee- } \\
\text { ring [Prozessreorganisation] }\end{array}$ & $0,87 \%$ & Other & & organizational learning & $1,50 \%$ & Oscillating topic & \\
\hline \multirow[t]{2}{*}{ • } & intranet & $0,84 \%$ & Fad & $\boldsymbol{\nabla}$ & education & $1,49 \%$ & Recurring fad & $\boldsymbol{\nabla}$ \\
\hline & $\begin{array}{l}\text { virtual corporations } \\
\text { [Virtuelle Unternehmen] }\end{array}$ & $0,82 \%$ & Other & $\nabla$ & e-mail system & $1,49 \%$ & Recurring fad & $\boldsymbol{\nabla}$ \\
\hline
\end{tabular}




\begin{tabular}{|c|c|c|c|c|c|c|c|c|}
\hline Anglicism & BISE & Frequency & Course pattern & & IS & Frequency & Course pattern & \\
\hline \multirow[t]{2}{*}{ - } & e-procurement & $0,80 \%$ & Fad & $\boldsymbol{\nabla}$ & software engineering & $1,47 \%$ & Recurring fad & $\boldsymbol{\nabla}$ \\
\hline & $\begin{array}{l}\text { development environment } \\
\text { [Entwicklungsumgebung] }\end{array}$ & $0,80 \%$ & Other & $\boldsymbol{\nabla}$ & communication & $1,45 \%$ & Recurring fad & $\boldsymbol{\nabla}$ \\
\hline • & change management & $0,80 \%$ & Other & $\Delta$ & website & $1,45 \%$ & Other & $\Delta$ \\
\hline • & $\begin{array}{l}\text { Online Analytical } \\
\text { Processing (OLAP) }\end{array}$ & $0,80 \%$ & Recurring fad & & $\begin{array}{l}\text { Electronic Data } \\
\text { Interchange (EDI)* }\end{array}$ & $1,44 \%$ & Oscillating topic & \\
\hline \multirow[t]{2}{*}{ - } & balanced scorecard & $0,79 \%$ & $\mathrm{Fad}$ & & teams in the workplace & $1,43 \%$ & Oscillating topic & \\
\hline & database [Datenbank] & $0,78 \%$ & Negative trend & & measurement & $1,38 \%$ & Oscillating topic & \\
\hline • & web 2.0 & $0,76 \%$ & Other & $\Delta$ & investment & $1,35 \%$ & Recurring fad & $\Delta$ \\
\hline • & $\begin{array}{l}\text { Customer Relationship } \\
\text { Management (CRM) }\end{array}$ & $0,76 \%$ & Fad & & strategic planning & $1,30 \%$ & Oscillating topic & \\
\hline • & data mining & $0,75 \%$ & Oscillating topic & & computer industry & $1,30 \%$ & Other & $\boldsymbol{\nabla}$ \\
\hline \multirow[t]{6}{*}{ - } & $\begin{array}{l}\text { Enterprise Application } \\
\text { Integration (EAI) }\end{array}$ & $0,74 \%$ & Fad & & $\begin{array}{l}\text { Enterprise Resource } \\
\text { Planning (ERP)* }\end{array}$ & $1,29 \%$ & Other & $\Delta$ \\
\hline & $\begin{array}{l}\text { action model } \\
\text { [Vorgehensmodell] }\end{array}$ & $0,74 \%$ & Other & $\boldsymbol{\nabla}$ & performance & $1,27 \%$ & Recurring fad & $\Delta$ \\
\hline & portal & $0,73 \%$ & Fad & & telecommunication & $1,26 \%$ & Oscillating topic & \\
\hline & $\begin{array}{l}\text { multi agent systems } \\
\text { [Multi-Agenten-Systeme] }\end{array}$ & $0,70 \%$ & Oscillating topic & & communication technology & $1,24 \%$ & Recurring fad & $\boldsymbol{\nabla}$ \\
\hline & $\begin{array}{l}\text { data protection } \\
\text { [Datenschutz] }\end{array}$ & $0,70 \%$ & Other & $\Delta$ & internet service & $1,23 \%$ & Recurring fad & $\Delta$ \\
\hline & $\begin{array}{l}\text { software agent } \\
\text { [Software-Agent] }\end{array}$ & $0,69 \%$ & Recurring fad & $\boldsymbol{\nabla}$ & competitive advantage & $1,22 \%$ & Oscillating topic & \\
\hline \multirow[t]{2}{*}{ - } & online shop & $0,69 \%$ & Oscillating topic & & computer user & $1,21 \%$ & Other & $\boldsymbol{\nabla}$ \\
\hline & $\begin{array}{l}\text { object orientation } \\
\text { [Objektorientierung] }\end{array}$ & $0,67 \%$ & Fad & & $\begin{array}{l}\text { human-computer } \\
\text { interaction }\end{array}$ & $1,21 \%$ & Other & $\boldsymbol{\nabla}$ \\
\hline
\end{tabular}

interesting, stating that BISE and IS are equally influenced by fads. At the beginning of their article, Frank et al. formulate the thesis - based on plausible arguments - that BISE deals more intensively with fads than IS ("BISE research is more susceptible to short-lived topics”, p. 397). Their findings, however, show that both BISE and IS are influenced by fads - consequently, there is no difference between the two disciplines. A possible reason for this finding, which Frank et al. did not expect either ("The proposition of IS research being less susceptible to fads than BISE research could not be supported", p. 403) may be the fact that the data used for the test of the hypothesis are not sufficiently representative, generalizable, and objective ("our approach is likely to cause three main objections”, p. 395). The present investigation, therefore, makes a contribution by compensating some limitations of the study by Frank et al. as we apply a quantitative design based on secondary-statistical data.

In IS, significantly more oscillating topics (28 vs. 14 percent) and recurring fads (42 vs. 20 percent) can be found than in
BISE. In BISE, 18 percent of recurring fads indicate an increasing and 82 percent a decreasing tendency, whereas in IS 43 percent are rising and 57 percent are falling (Tab. 1, rising $<\boldsymbol{\Delta}>$ and falling $<\boldsymbol{\nabla}>$ ). The percentage of developments that follow none of the five defined patterns is 30 percent for BISE and 18 percent for IS. In BISE 60 percent of the topics grouped in the class "Other" show an increasing and 40 percent a decreasing tendency, whereas in IS 22 percent demonstrate an increasing and 78 percent a decreasing tendency.

\subsection{Which developmental patterns are shown by the individual components and the dyads of the HU-TA-TE classification in BISE and IS research?}

So far, we presented results with respect to the terms and topics in BISE and IS at a high degree of detail (see Tab. 1). To illustrate the results at an abstract level, we classified the 100 most frequently mentioned terms in BISE and IS into one of the classes HU, TA, TE, HU-TA, HU-TE, or TA-TE (the exact procedure has already been explained in section
4.2). Tab. 2 shows that in BISE and IS the dyad TA-TE is dominant (31 percent). Significant differences between BISE and IS exist in case of the component TE (BISE $>$ IS) and the dyad HU-TE (IS >BISE); these results reflect the differences in research traditions in BISE (design-orientation) and IS (behaviorism).

Regarding the developmental patterns of each of the six classes, we calculated the function of the linear regression line for the period from 1994 to 2007 for both BISE and IS. Here, the slope $k$ of the line is of particular interest (see section 5) because it expresses whether the importance of a class increased or decreased during the investigation period. As the results in Tab. 2 indicate, the importance of two classes increased in BISE during the investigation period. The class HUTA only marginally gained in importance $(k=0.0507)$, whereas the class TA-TE gained significantly $(k=1.3622)$. Moreover, it has to be noted that none of the $100 \mathrm{key}$ words could be assigned to the class $\mathrm{HU}$ in BISE, and that the importance of all other classes developed equally in BISE and IS except for TA-TE, which means 


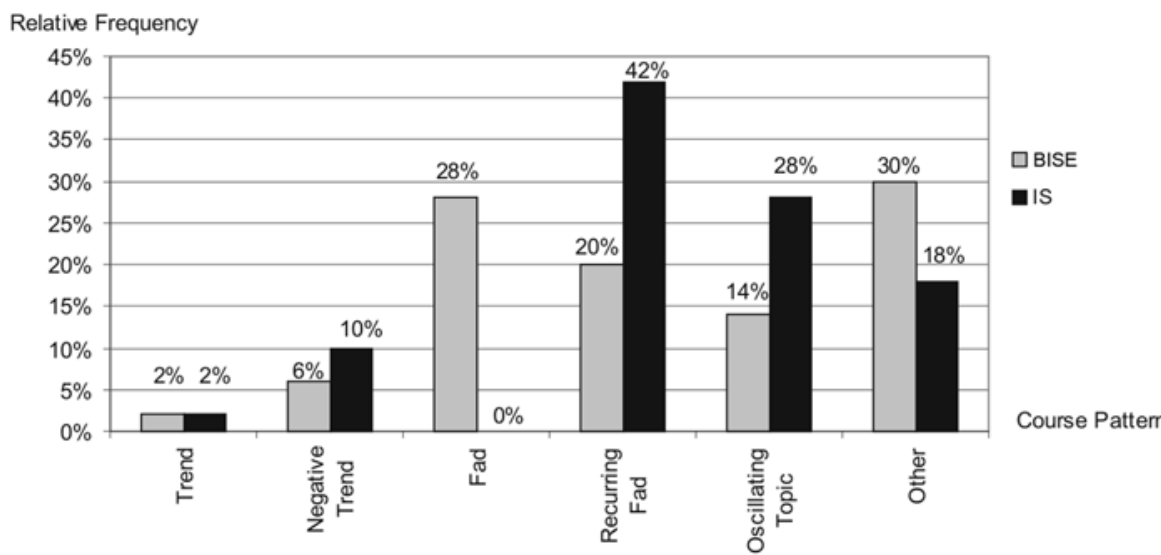

that the relevance of the classes has either decreased (TA, TE, HU-TE) or increased (HU-TA) in both disciplines. One conclusion from these results is that the developments of BISE and IS show significant similarities at an abstract level of view, although the development of specific topical areas, as described in Section 6.2, is different in many cases.

\section{Implications of the results for BISE and IS}

The main findings of this study are: (i) the diversity of terms used in scientific literature is higher in BISE than in IS research; (ii) BISE is strongly influenced by fads; (iii) in both BISE and IS only one trend could be identified, and (iv) in IS, there are more negative trends, recurring fads, and oscillating topics than in BISE (see the course patterns in section 5). In the following, we discuss implications of these results for BISE and IS research.

\subsection{Diversity of terms and topics}

By analyzing titles, abstracts, and keywords, we documented 4.09 buzzwords for each BISE paper and only 2.03 for each IS article on average. Therefore, a key finding of this study is that the diversity of terms used in BISE is 2.01 higher than in IS.

In IS, a debate on the opportunities and risks of a strong thematic diversity has been taking place for a long time (e. g., Vessey et al. 2002). In the past, concerns have been raised that a lack of a topical core could lead to the absorption of the discipline or substantial parts into its neighboring disciplines (e. g., computer science, business administration, or psychology). Benbasat and Weber (1996, pp. 389/397), for example, write:
"[W]e need to rethink whether the discipline can continue to exist as the loose confederation of different interest areas us to a state where (a) we have difficulty distinguishing ourselves from others who are bigger and more powerful, and (b) deemed problematical by our colleagues in other disciplines. We run the risk, therefore, that diversity will be the miasma that spells the demise of the discipline [...] there is a need to articulate the core of the discipline."

Banville and Landry (1989, p. 48) mention similar critique. They comment very sarcastically on the diversity of research objects, which is especially a result of the short "validity" of single topics, by asking what the next week's gadget will be. In a similar vein, following Kuhn (1962), one might argue that researchers in particular leave their paradigm - in the sense of a thematic mission - when it does no longer contribute to achieving desired goals (e. g., opportunities for third-party funds or publication in a top journal).

If the researchers of BISE and IS determine the level of topical diversity on which the discipline should be based in the future, a careful consideration of the arguments for and against this issue is necessary. In particular, there are three main advantages: First, diversity promotes creativity; second, it increases the opportunities for third-party funds by research funding bodies and the private sector; and third, it contributes to the principle of academic freedom - "If academia stands for anything, it stands for the freedom to pursue problems and exploit opportunities for expanding knowledge" (Robey 1996, p. 404).

Krcmar (1999, pp. 186 f) argues for a distinctive diversity of topics in BISE just [...] in our view diversity has now taken our intellectual contributions, at best, are
Fig. 8 Dissemination of course patterns

as Robey (1996) does for IS, especially because within a scientific discipline - in contrast to companies - no top management exists that decides on the future orientation (i. e., the thematic priorities):

"While in companies, the establishment of a mission statement can be considered as a strategic management task as it has both a meaningful and framework setting effect, it is very questionable to what extent the scientific disciplines should not better commit themselves to the objective of diversity instead of a unified strategic management. In this case, the proposal for ONE vision for THE BISE is certainly not futile, but would function as a starting point for discourse and not as trigger for finally bringing a unification process of all experts back to one positive conclusion." (Capital letters in the original; translated into the English language.)

Despite the pleas for diversity of terms and topics, two tasks for scientific communities remain, such as the section "Business Information Systems" in the German Academic Association for Business Research or the Association for Information Systems (AIS): First, when time is ripe, frameworks and other classifications (e. g., curriculum recommendations, research guides, encyclopedias) have to be developed in which fads are reduced to their essence. Second, the scientists, some of which are highly specialized, should be motivated to cooperate more closely beyond their specific field (e. g., in scientific programs or seminars).

\subsection{Fads}

If a topic is investigated in an abstract way, it is less likely to develop the course pattern of a fad. In other words: A high degree of specification goes along with a relatively rapid change of topics. Tab. 1 shows, for 
example, that the abstract topic Internet is neither a fad in BISE nor in IS. Specific Internet topics, such as many "e-themes", in BISE usually show the course pattern of a fad (e. g., e-commerce and e-business in Tab. 1).

Intensively dealing with fads is often seen critically. It is remarkable that not only science (e. g., Kieser 1996; Kieser and Walgenbach 2003), but also business practice occasionally considers the strong move towards fadlike topics as negative. Larry Ellison, founder and CEO of Oracle, expressed his position, for example, in commenting on the concept of cloud computing: "When will this nonsense stop? IT is the only industry more driven by fashion topics than the world of women's clothing." (cited from Computerwoche 2008; translated into the English language). Heilmann states regarding the strong orientation towards fads that "fadlike issues unfortunately bear a relatively high importance due to research funding" (cited from an interview study by Lange 2006; translated into the English language). Similarly, also Rautenstrauch (1999, p. 187) considers fashion topics as critical - he states pointedly:

"Also in BISE, at least occasionally (but not always!) fads are adopted as general principles of "practical orientation", instead of principles "separating the wheat from the chaff" as has been rightly claimed. We should have reason to think about the fact that, for example, after a series of candidate lectures a well-disposed colleague from a neighboring discipline wonders, "what distinguishes a BISE researcher from a management consultant". The reason for the question was that, apart from two exceptions, the candidates held talks of the kind "we carried out a project with the company XY - this was the requirement - that was the output" (translated into the English language).

The intense engagement in fads, and that is a central message of this paper, has also positive effects. In particular because of its increased practical orientation, BISE is characterized by fads to a higher extent than IS. The orientation towards fads is often associated with the ability and willingness to quickly consider new developments in practice. A scientific discipline's strong ability and willingness to orient towards fads - if viewed from a macroeconomic perspective - may contribute to

\begin{tabular}{|c|c|c|c|}
\hline & $\begin{array}{l}\text { Slope } k \text { of the Linear } \\
\text { Regression Line }\end{array}$ & & $\begin{array}{l}\text { Slope } k \text { of the Linear } \\
\text { Regression Line }\end{array}$ \\
\hline Human (HU) & & Human-Task (HU-TA) & \\
\hline BISE (0 \%) & no term classified & BISE (11\%) & 0.0507 \\
\hline IS (3 \%) & -0.2377 & IS (10\%) & 0.1438 \\
\hline Task (TA) & & Human-Technology (HU-TE) & \\
\hline BISE (24 \%) & -0.5575 & BISE (10 \%) & -0.2176 \\
\hline IS (21\%) & -0.5531 & IS (19\%) & -0.0714 \\
\hline Technology (TE) & & Task-Technology (TA-TE) & \\
\hline BISE (24 \%) & -1.1401 & BISE (31 \%) & 1.3622 \\
\hline IS (16\%) & -2.5060 & IS (31\%) & -1.4082 \\
\hline
\end{tabular}

leveraging first-mover advantages (e. g., Suarez and Lanzolla 2008).

Against the background of the rigor vs. relevance debate (see, for example, special issues of MIS Quarterly in 1999 or Communications of the AIS in 2001), which also affects BISE due to the increasing pressure to internationalize (Frank 2003, p. 282; Frank et al. 2008), a scientific discourse has to answer the question to what extent dealing with fads makes a positive contribution to the relevance of research. For example, the discussion of the year-2000problem within a short period helped to create a strong awareness for the issue, which effectively contributed to addressing this challenge (Berghel 1998; Faulkner 1998; Knolmayer 1997; Lewis 1999).

High relevance of research - referring to the frequency of dealing with practicerelated issues - has the effect that business and government are willing to provide third-party funds for the execution of relevant research and development projects as they promise the solution of currently existing problems. A quote from the interview study by Lange (2006, p. 24) expresses this fact: "Somehow, you try to thematically fight or swim at the forefront - because the funding of the universities is becoming worse. We have to strive for third-party funds and the sponsors are also very strongly influenced by current topics" (translated into the English language). An analysis of this quote allows for the interpretation that so far dealing with fashions has mainly been the result of scarce financial resources. One example of the past substantiating this view is that the investigation of the Computer Integrated Manufacturing (CIM) concepts and methods would have been more useful if carried out at a smaller number of research institutes for longer time peri- ods (instead of investigations at a larger number of institutes for a shorter period). Today, many aspects of the CIM concept are investigated by drawing upon new names, such as Supply Chain Management or Manufacturing Execution Systems, but without sufficiently reflecting existing knowledge gained from previous CIM research. A continuous development of the already existing research centers would probably have been more appropriate (Mertens 1995).

With respect to the future orientation of BISE, we believe it is useful to aim at distinction through a strong orientation towards practice, which can be in line with scientific standards (Gadenne 1997; Wohlgenannt 1969, pp. $57 \mathrm{ff}$ ). The aim of such a strategic positioning is to further develop the strength of rapidly solving problems in practice in order to provide a direct benefit for society, especially for businesses and governments. What relevance within our society would we ascribe to medicine, if it did not focus on the development of medication and therapies but only the development of descriptive and explanatory models? BISE should therefore - as documented in the BISE profile since the mid 1990s (WKWI 1994, pp. 80 f) - not only address the objective of description and explanation, rather, it should also focus on design science, which may of course be associated with a concentration on fashion topics.

In IS many recurring fads but no single fad have been identified (see Fig. 2). However, a reasonable engagement in fads may contribute to increasing the relevance of research. Against the background of the continuing criticism of too little practical relevance of IS research - Klein and Rowe (2008, p. 675), for example, write: "One of the major challenges facing the field of MIS 
today is to become more practically relevant so that it can better serve its business and public sector stakeholders" - it would be a possible strategy to achieve a higher degree of practical relevance by engaging in those issues, which are of high priority in business practice at a certain time; even when facing the risk of temporarily attributing less emphasis on theoretical research and a cumulative research progress.

\subsection{Trends}

In the period of 1994 to 2007, in both BISE and IS research only one trend could be identified: business intelligence in BISE research and trust in IS research (see section 6). If a topic follows the course pattern of a trend, this means that the members of a scientific discipline are increasingly studying the topic. This increases the opportunity for a sustainable knowledge progress, especially because a cumulative research tradition can be established.

Mertens (2002) analyzed the literature dealing with the topic business intelligence (BI) and found out that seven perspectives on the issue can be identified: (i) BI as a continuation of data and information processing, (ii) BI as a filter for dealing with information overload, (iii) BI as a management information system with rapid and flexible analyses, (iv) BI as an early warning system, (v) BI as a data warehouse, (vi) BI as an information and knowledge storage system, and (vii) BI as a process. A chronological investigation of the development of BI contents shows that at the beginning of the 2000s a strong focus was set on technological foundations (e. g., data warehouse and data mining), while in the mid2000s researchers concentrated on applications and organizational issues (e. g., BI and decision-making processes) (see e. g., the special issues 222 and 247 of HMD Praxis der Wirtschaftsinformatik from the years 2001 and 2006). We have found in the present study that the topic was examined from different perspectives, consistently using the term BI with increasing intensity in the investigation period. The fact that the issue was increasingly addressed from different perspectives could be an indication that the design of BI systems and the investigation of their effects in the organizational context give rise to its own theoretical core, which may help to answer the following question: How are information systems supposed to be designed and used to address specific information needs (concerning an organization's internal and external circumstances) for acting in a more efficient and more economical way?

The development of the only IS-trend trust was - in contrast to $B I$ in BISE not triggered by a technological innovation but by a theoretical core outside its own field. In the late 1950s and 1960s, researchers in psychology started to intensively explore the issue of trust (e. g., Giffin 1967; Rotter 1967; Strickland 1958). Starting in the 1970s, also business administration research increasingly addressed this topic, especially in the fields of organizational behavior and marketing (Grayson et al. 2008; Mayer et al. 1995; Zand 1972). Finally, in the last decade, also researchers in economics began to engage in this topic (King-Casas et al. 2005; Kosfeld et al. 2005; Sutter and Kocher 2007; Zak and Knack 2001). In IS, researchers have been intensively examining the issue of trust for almost ten years. The topic's importance therefore began to increase at a time when also the Internet became more relevant, especially because trust plays a central role in e-commerce (Ba and Pavlou 2002; Gefen 2000; Gefen et al. 2003; Kim and Benbasat 2006). Examining the references mentioned in IS contributions on trust today, we recognize that the authors rely on the findings of related disciplines (e. g., psychology, business administration, and economics) and the IS itself. This allows for reflecting a wide range of different perspectives on the issue, which is a key requirement of cumulative research.

\subsection{Negative trends, recurring fads, and oscillating topics}

In IS, there are more negative trends, recurring fads, and oscillating topics than in BISE. Negative trends are characterized by a continuous decline in addressing a specific theme (Fig. 2 and Fig. 4). From a resource-based view, it may be appropriate for a scientific community to quickly decide (and not in a lengthy process) on giving up the examination of a less promising topic (e. g., by no longer publishing special issues). Available resources can then be used for the exploration of new issues that are especially relevant in business practice. Since BISE is characterized by a large number of fads, it can be concluded that it shows the higher ability and/or willingness to quickly abandon non-promising topics. For IS, the recommendation could be given to critically question the consideration of steadily declining issues in the future, and, if reasonable, suspend these faster in order to, for example, invest released research budgets into topics which are important in practice and/or science at a certain point in time.

The main difference between recurring fads and oscillating topics is that the latter show a constant level of scientific engagement in the given period, which is characterized by short and cyclical ups and downs (Fig. 2). Thus, oscillating themes are important for a sustainable knowledge progress, while the many recurring fads with falling tendency - similar to the negative trends - hardly contribute to the knowledge progress, but bind valuable resources. Therefore, both for BISE and IS it is important in the future to critically evaluate new topics to find out if they have not already been unsuccessfully investigated in the past.

\section{Limitations}

In this article, we presented an analysis of research topics and their developments in BISE and IS. As a basis for our investigation, we used terms which have been identified by the analysis of titles, abstracts, and keywords of journal articles. The validity of the findings is high if one agrees that the chosen journals in each discipline are considered to be representative for the respective field. Moreover, with respect to our sample we have to note that there are articles associated with a scientific community which are not necessarily published in journals of the field; an example would be "IT Doesn't Matter" by Carr (2003) which was published in Harvard Business Review.

An assumption of the present study is that the semantic content of each studied term remained constant during the investigation period from 1994 to 2007. If this semantic content changed for many of our terms at a high extent, then this would negatively affect the validity of the presented findings. The following example will illustrate this fact: The only trend found in BISE is business intelligence. Maybe this topic appears as a trend as in recent years several contributions on the topics of management information systems, decision support systems, data mining, and the like have been published using the abstract term business intelligence. Therefore, the frequency of 
Fig. 9 Course patterns in dependence of the investigation period (e-business)

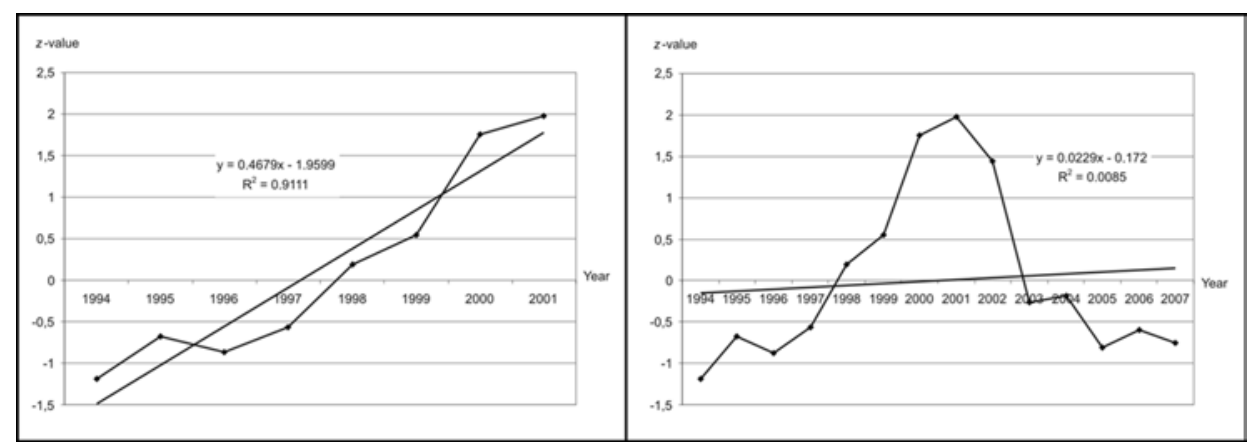

mentioning business intelligence might be explained by the fact that a collective term evolved from separate terms.

It should also be noted that the practical relevance of research is not only determined by the mere discussion of fads. Instead, also the research quality significantly contributes to its relevance. A quantification of research quality could, for example, be based on published and subsequently adopted techniques, methods, tools, patents, and spin-offs.

When interpreting the present results, it is important to keep in mind that it is not possible to directly draw conclusions for the future development of specific topics. The Delphi method, an accepted forecasting method, might lead to reliable predictions (Dalkey and Helmer 1963). In BISE and IS, Delphi studies have already been conducted which, among other things, make statements regarding the potential future development of research areas, topics, and scientific objectives (e. g., Brancheau and Wetherbe 1987; Dickson et al. 1984; Heinzl et al. 2001; Niederman et al. 1991; König et al. 1995). Heilmann and Heinrich (2006) evaluated, for example, the forecast quality of a Delphi study by Heinzl et al. (2001); as a result, the authors noted (p. 105) that 12 of the 15 predicted scientific objects were, in fact, addressed in publications in the period from 2003 to 2005.

The topical areas analyzed in the present study are - in analogy to products and organizations - subject to a life-cycle (see Heinzl 1996, pp. 69 ff). When interpreting the presented findings we therefore have to keep in mind that the classification of a particular topic with one of the defined idealized course patterns depends on the examination period. This means that a longer or shorter period influences the assignment of a topic to an idealized pattern. In Fig. 9, we present the development of the topic $e$-business in two time periods as an example. In the period from 1994 to
2001, e-business has the pattern of a trend, for a longer period (1994 to 2007), however, it follows the pattern of a fad.

The influence of a chosen period on the pattern of a topic constitutes a problem which is unavoidable in studies such as the present one. In the best case, researchers may analyze the development of research topics from the beginnings of a discipline to the present. Mertens (1995) examined the period from 1975 to 1994 . Therefore, his analysis started at exactly the same time as the founding of the Section "Business Information Systems" in the German Academic Association for Business Research, which was one of the major milestones in the BISE development (Heinrich et al. 2007, p. 40). ${ }^{4}$ The present study is a direct follow-up investigation of the study of Mertens (1995) and extends it to the present.

In this context, it should be noted that our chosen observation period of 14 years is relatively long as well as the amount of eight journals and 8,257 papers is very extensive. Other content analyses in BISE and IS, to the best of our knowledge, investigated shorter periods and a smaller number of journals and papers. Wilde and Hess (2007), for example, analyzed 300 articles from 11 years of the journal WIRTSCHAFTSINFORMATIK in a recently published study to gain insights into the methodological development of the discipline. Riedl et al. (2008) summarized 20 studies in a meta-analysis providing information on the adoption of research methods in IS. The descriptive analysis (see Tab. 1) of all 20 studies shows the following: on average, 862 articles $(s=538$, max $=2098$, min $=83$ ) from 9.2 years $(s=5.06, \max =21, \min =2)$ on the basis

\footnotetext{
4 The IS equivalent to the Section "Business Information Systems" in the German Academic Association for Business Research, the Association for Information Systems (AIS), has been founded in 1994.
}

of 6.95 journals $(s=3.81$, max $=15$, min $=2)$ are analyzed.

Finally, we would like to point out that the 20 studies investigated by Riedl et al. and all other content analyses on the development of topics and methods in a scientific discipline - and hence also the present study - always develop insights which necessarily refer to a particular period in the past. The value of content studies including the value of the present article - can therefore be mainly seen in revealing important historical facts (in this case the development of topical areas). Knowledge of one's own history, especially with respect to topics and methods, is a prerequisite for the development of one's own identity, which in turn may influence the future success of a discipline (Klein and Hirschheim 2008).

\section{Conclusion and outlook}

The internationalization of research in BISE increasingly influences the actions of many scholars in the German-speaking countries. The research program of IS is often used as an ideal model. On the one hand, IS has distinct strengths (especially regarding the rigor of research methods), but on the other hand, IS has weaknesses compared to BISE (in particular the lower practical relevance of its research). BISE is thematically more specific and more diverse than IS and the number of fads is higher in BISE. This finding leads us to the assumption that a key strength of BISE is that it acts "on the pulse of time". This is essential for a discipline whose research object is characterized by the component technology. We recommend that applied sciences, and BISE and IS in particular, should be strongly focused on practical aspects in order to avoid the risk that business and administration do not recognize the possible benefits and implications of its research findings. Nevertheless we 


\section{Abstract \\ Katharina Steininger, René Riedl, \\ Friedrich Roithmayr, Peter Mertens \\ Fads and Trends in Business and Information Systems Engineering and Information Systems Research - A Comparative Literature Analysis}

The business and information systems engineering (BISE) discipline, dominating in the German-speaking countries, where it is called "Wirtschaftsinformatik", is currently undergoing a phase of increasing internationalization and the U.S.-based Information Systems (IS) discipline is often considered an ideal. Studies show that BISE has often dealt with fads in the past - for IS there are no findings reporting on the diffusion of fads. The objective of the paper is to close this research gap. The authors conducted a literature analysis to investigate the development of topics and terms in BISE and IS from 1994 to 2007. Titles, abstracts and keywords of 2,564 articles in three BISE journals and 5,647 articles in five IS journals were analyzed. The results show that BISE is topically more diverse and concrete than IS. In addition, the rate of fads is higher in BISE than IS. Being engaged in fads is not necessarily negative - rather, it may considerably contribute to the relevance of research. However, it has to be considered that an overly intense orientation on fads may negatively influence a cumulative research progress. Hence, the authors conclude that for BISE and IS, which both have a theoretical and pragmatic mission, a balanced ratio of short- and long-term topics seems appropriate.

Keywords: Fads, Trends, Topical diversity, Terminology, Information Systems, Literature analysis argue that BISE researchers should also pay attention to theoretical research (as IS researchers do), in particular for dealing with the occasionally asserted criticism for the lack of willingness and/or ability to abstract thinking in BISE (e. g., Heinrich 2005, p. 110).

The findings of the present article show that terms which have once been introduced in BISE are subsequently used to a lesser extent than in IS. This fact is particularly disadvantageous for the establishment of a cumulative research tradition (see Keen 1980). Therefore, it seems important to us that BISE researchers (regardless of whether they act in the role of authors, reviewers, and editors) ensure that key terms in a particular area of research will be consistently (re)used in the future. New terms should only be used if they refer to something different from what is already known. For example, in BISE the term Application Service Providing (ASP) became known as a form of IT outsourcing at the beginning of the $2000 \mathrm{~s}$ and today the same phenomenon is usually referred to as Software as a Service (Knolmayer 2000; http://www.saas-forum.net/), although both terms describe the same phenomenon of offering software as a service via the Internet. Future research could examine such precursor/successor relationships of terms in order to make similarities and differences to the results presented here more transparent.

Finally, we conclude this article by discussing the influence of topics on research methods, as methodological discourse in BISE gains importance (Wilde and Hess 2007). If we assume a causality of the type method follows topic (which corresponds to the ideal research process; Bortz and Döring 2006), then the diversity of topics identified in BISE may contribute to the pluralism of methods which has been discussed since the $1990 \mathrm{~s}$ (Frank 1997, p. 32; König et al. 1996, pp. 43 ff; Wilde and Hess 2007, p. 284). For IS research, it is well known that research topics correlate with research methods applied (Benbasat 1984; Choudrie and Dwivedi 2005; Grover et al. 1993; Jenkins 1985; Palvia et al. 2003). Palvia et al. (2003, pp. $301 \mathrm{f}$ ), for example, demonstrated for the IS discipline that case studies are primarily used for studying topics in the field of e-commerce, while decision support systems are primarily analyzed on the basis of laboratory experiments. The results of this study can be taken as a starting point for analyses which aim at validating the relationship between topic and method used in BISE. When BISE researchers proceed in future, however, it is important that they not only cover a broad spectrum of topics and methods, but in particular take the quality of the methods used into account, too (Heinrich 2005). Here, BISE can learn from IS which has been publishing guidelines for the use of different methods for a long time (e. g., Benbasat et al. 1987; Dubé and Paré 2003; Jarvenpaa et al. 1985; Kaplan and Duchon 1988; King and He 2005; Lee 1989; Straub 1989), which researchers then consider in their method application.

\section{Acknowledgments}

The authors would like to thank the participants of the $7^{\text {th }}$ Qualitative Content Analysis Workshop 2007 in Velden, Austria, and the participants of the track "Quo vadis Wirtschaftsinformatik" at the Multikonferenz Wirtschaftsinformatik 2008, Munich, for their valuable comments on earlier versions of this paper. We also thank Nenad Baotic, Christian Beier, Michael Hitsch, Elisabeth Greibl, Peter Kaar, Dieter Moser, Magdalena Moser, and Johannes Voglsam for assistance with data collection and coding. Finally, we are grateful to David Rückel who provided valuable help during data analysis.

\section{References}

Alavi M, Carlson P (1992) A review of MIS research and disciplinary development. Journal of Management Information Systems 8(4):45-62

Atteslander P (2006) Methoden der empirischen Sozialforschung, 11th edn. de Gruyter, Berlin

Ba S, Pavlou P (2002) Evidence of the effect of trust building technology in electronic markets: Price premiums and buyer behavior. MIS Quarterly 26(3):243-268

Banville C, Landry M (1989) Can the field of MIS be disciplined? Communications of the ACM 32(1):48-60

Barki H, Rivard S, Talbot J (1988) An information systems keyword classification scheme. MIS Quarterly 12(2):298-322

Barki H, Rivard S, Talbot J (1993) A keyword classification scheme for IS research literature: An update. MIS Quarterly 17(2):209-226

Becker J (2008) Ein Plädoyer für die gestaltungsorientierte Wirtschaftsinformatik. In: Myrach T, Jung R (eds) Quo vadis Wirtschaftsinformatik Festschrift für Prof. Gerhard F. Knolmayer zum 60. Geburtstag. Gabler, Wiesbaden, pp 3-21

Benbasat I (1984) An analysis of research metho- 
dologies. In: McFarlan WF (ed) The information systems research challenge. Proceedings of the Harvard Business School Research Colloquium, Harvard Business School Press, pp 47-85

Benbasat I, Goldstein DK, Mead M (1987) The case research strategy in studies of information systems. MIS Quarterly 11(3):354-366

Benbasat I, Weber R (1996) Research commentary: Rethinking "Diversity" in information systems research. Information Systems Research 7(4):389-399

Berghel H (1998) The year 2000 problem and the new riddle of induction. Communications of the ACM 41(3):13-17

Bortz J (2005) Statistik für Human- und Sozialwissenschaftler, 6th edn. Springer, Heidelberg

Bortz J, Döring N (2006) Forschungsmethoden und Evaluation für Human- und Sozialwissenschaftler, 4th edn. Springer, Heidelberg

Brancheau JC, Wetherbe JC (1987) Key issues in information systems management. MIS Quarterly $11(1): 23-45$

Carr NG (2003) IT doesn't matter. Harvard Business Review 81(5):41-49

Chen C, Song, IIY, Yuan X, Zhang J (2008) The thematic and citation landscape of data and knowledge engineering (1985-2007). Data \& Knowledge Engineering 67(2):234-259

Chen W, Hirschheim R (2004) A paradigmatic and methodological examination of information systems research from 1991 to 2001. Information Systems Journal 14(3):197-235

Chmielewicz K (1994) Forschungskonzeptionen der Wirtschaftswissenschaften, 3rd edn. Schäffer-Poeschel, Stuttgart

Choudrie J, Dwivedi YK (2005) Investigating the research approaches for examining technology adoption issues. Journal of Research Practice 1(1):D1, pp 1-12

Claver E, Gonzalez R, Llopis J (2000) An analysis of research in information systems (1981-1997). Information \& Management 37(4):107-119

Cohen J (1960) A coefficient of agreement for nominal scales. Educational and Psychological Measurement 20(1):37-46

Computerwoche (2008) Cloud Computing erhitzt Gemüter. Computerwoche 41:5

Dalkey N, Helmer O (1963) An experimental application of the delphi method to the use of experts. Management Science 9(3):458-467

Dickson GW, Leitheiser RL, Wetherbe JC, Nechis M (1984) Key information systems issues for the 1980's. MIS Quarterly 8(3):135-159

Diekmann A (2006) Empirische Sozialforschung, 16th edn. Rowohlt, Reinbeck

Dubé L, Paré G (2003) Rigor in information systems positivist case research: current practices, trends, and recommendations. MIS Quarterly 27(4):597-635

Farhoomand A, Drury DH (1999) A historiographical examination of information systems. Communications of the AIS 1:1-20

Faulkner A (1998) The year 2000 problem and its implications for the information profession. Journal of Information Science 24(4):255-265

Fenn J (1995) When to leap on the hype cycle. Gartner Group, http://www.gartner.com. Accessed 2008-01-18
Frank U (1997) Erfahrung, Erkenntnis und Wirklichkeitsgestaltung: Anmerkungen zur Rolle der Empirie in der Wirtschaftsinformatik. Grün O, Heinrich LJ (eds) Wirtschaftsinformatik - Ergebnisse empirischer Forschung. Springer, Wien, pp 21-35

Frank U (2003) Einige Gründe für eine Wiederbelebung der Wissenschaftstheorie. Die Betriebswirtschaft 63(3):278-292

Frank U (2008) Herausforderungen der Wirtschaftsinformatik in Zeiten des Wandels. In: Myrach, Thomas, Jung, Reinhard (eds) Quo vadis Wirtschaftsinformatik - Festschrift für Prof. Gerhard F. Knolmayer zum 60. Geburtstag. Gabler, Wiesbaden, pp 37-56

Frank U, Schauer C, Wigand R (2008) Different paths of development of two information systems communities: A comparative study based on peer interviews. Communications of the AIS 22(21):391-412

Gadenne V (1997) Wissenschaftstheoretische Grundlagen der Wirtschaftsinformatik. In: Grün O, Heinrich LJ (eds) Wirtschaftsinformatik - Ergebnisse empirischer Forschung. Springer, Wien, pp 7-20

Gefen D (2000) E-commerce: The role of familiarity and trust. The International Journal of Management Science 28(6):725-737

Gefen D, Karahanna E, Straub DW (2003) Trust and TAM in online shopping: An integrated model. MIS Quarterly 27(1):51-90

Giffin K (1967) The contribution of studies of source credibility to a theory of interpersonal trust in the communication department. Psychological Bulletin 68(2):104-120

Grayson K, Johnson D, Chen DR (2008) Is firm trust essential in a trusted environment? How trust in the business context influences customers. Journal of Marketing Research 45(2):241256

Grover V, Lee CC, Durand D (1993) Analyzing methodological rigor of MIS survey research from 1980-1989. Information \& Management 24(6):305-317

Heidecke F, Back A, Brenner W (2005) Dissertationserhebung in der Wirtschaftsinformatik 2004. WIRTSCHAFTSINFORMATIK 47(3):226235

Heilmann H, Heinrich LJ (2006) Erkenntnisobjekte der Wirtschaftsinformatik. HMD - Praxis der Wirtschaftsinformatik 43(250):99-108

Heinrich LJ (2002) Informationsmanagement, 7th edn. Oldenbourg, Wien

Heinrich LJ (2005) Forschungsmethodik einer Integrationsdisziplin: Ein Beitrag zur Geschichte der Wirtschaftsinformatik. NTM International Journal of History and Ethics of Natural Sciences, Technology and Medicine 13(2):104-117 Heinrich LJ, Heinzl A, Roithmayr F (2007) Wirtschaftsinformatik - Einführung und Grundlegung, 3rd edn. Oldenbourg, Wien

Heinzl A (1996) Die Evolution der betrieblichen DV-Abteilung: Eine lebenszyklustheoretische Analyse. Physica, Heidelberg

Heinzl A, König W, Hack J (2001) Erkenntnisziele der Wirtschaftsinformatik in den nächsten drei und zehn Jahren. WIRTSCHAFTSINFORMATIK 43(6):223-233
Herzwurm G, Stelzer D (2008) Wirtschaftsinformatik versus Information Systems - Eine Gegenüberstellung. Arbeitsbericht 2008-01, Universität Ilmenau

Hugl U (1995) Qualitative Inhaltsanalyse und Mind-Mapping. Gabler, Wiesbaden

Jarvenpaa SL, Dickson GW, DeSanctis G (1985) Methodological issues in experimental IS research: Experiences and recommendations. MIS Quarterly 9(2):141-156

Jenkins MA (1985) Research methodologies and MIS research. In: Mumford E, Hirschheim R, Fitzgerald G, Wood-Harper T (eds) Research methods in information systems. Elsevier, Amsterdam, pp 103-117

Kaplan B, Duchon D (1988) Combining qualitative and quantitative methods in information systems research: A case study. MIS Quarterly 12(4):571-586

Keen P (1980) MIS Research: Reference disciplines and a cumulative tradition. In: McLean ER (ed) Proceedings of the 1st international conference on information systems. Philadelphia, pp 9-18

Kieser A (1996) Moden und Mythen des Organisierens. Die Betriebswirtschaft 56(1):21-31

Kieser A, Walgenbach P (2003) Organisation, 4th edn. Schäffer-Poeschl, Stuttgart

Kim D, Benbasat I (2006) The effect of trust-assuring arguments on customer trust in internet stores: Application of Toulmin's model of argumentation. Information Systems Research 17(3):286-300

King WR, He J (2005) External validity in IS survey research. Communications of the AIS 16:880894

King-Casas B, Tomlin D, Anen C, Camerer CF, Quartz SR, Montague PR (2005) Getting to know you: Reputation and trust in a two-person economic exchange. Science 308 (5718):78-83

Klein HK, Hirschheim R (2008) The structure of the IS discipline reconsidered: Implications and reflections from a community of practice perspective. Information and Organization 18:280-302

Klein HK, Rowe F (2008) Marshaling the professional experience of doctoral students: A contribution to the practical relevance debate. MIS Quarterly 32(4):675-686

Knolmayer G (1997) Das Jahr 2000-Problem: Medien-Spektakel oder Gefährdung der Funktionsfähigkeit des Wirtschaftssystems? WIRTSCHAFTSINFORMATIK 39(1):7-18

Knolmayer G (2000) Application service providing (ASP). WIRTSCHAFTSINFORMATIK 42(5):443446

König W, Heinzl A, von Poblotzki A (1995) Die zentralen Forschungsgegenstände der Wirtschaftsinformatik in den nächsten zehn Jahren. WIRTSCHAFTSINFORMATIK 37(6):558-569

König W, Heinzl A, Rumpf M-J, von Poblotzki A (1996) Zur Entwicklung der Forschungsmethoden und Theoriekerne der Wirtschaftsinformatik. Eine kombinierte Delphi- und AHP-Untersuchung. In: Heilmann H, Heinrich LJ, Roithmayr $F$ (eds) Information Engineering. Oldenbourg, München, pp 35-65

Kosfeld M, Heinrichs M, Zak PJ, Fischbacher U, 
Fehr E (2005) Oxytocin increases trust in humans. Nature 435(7042):673-676

Krcmar H (1999) Einige Anmerkungen zu "Von Leitbildern, Moden und Langfristzielen der Wirtschaftsinformatik" von Prof. Dr. Arno Rolf. WIRTSCHAFTSINFORMATIK 41(2):186-187

Krcmar H (2006) Informationsmanagement, 4th edn. Springer, Heidelberg

Krippendorff K (2004) Content analysis - An introduction to its methodology, 2nd edn. Sage, Thousand Oaks

Kuhn T (1962) The structure of scientific revolutions. University of Chicago Press, Chicago

Kurbel K (2008) Internationalisierung der Wirtschaftsinformatik. Weiter auf der Erfolgsspur oder in die Sackgasse? In: Myrach T, Jung R (eds) Quo vadis Wirtschaftsinformatik - Festschrift für Prof. Gerhard F. Knolmayer zum 60. Geburtstag. Gabler, Wiesbaden, pp 83-94

Landis RJ, Koch GG (1977) The measurement of observer agreement for categorical data. Biometrics 33(1):59-74

Lange C (2005) Ein Bezugsrahmen zur Beschreibung von Forschungsgegenständen und -methoden in Wirtschaftsinformatik und Information Systems. ICB-Research Report Nr. 1, Universität Duisburg-Essen

Lange C (2006) Entwicklung und Stand der Disziplinen Wirtschaftsinformatik und Information Systems - Interpretative Auswertung von Interviews: Teil III Ergebnisse zur Wirtschaftsinformatik. ICB-Research Report Nr. 4, Universität Duisburg-Essen

Laudon KC, Laudon JP (2002) Management information systems, 7th edn. Prentice Hall, New Jersey

Lee AS (1989) A scientific methodology for MIS case studies. IMIS Quarterly 13(1):33-50

Lewis H (1999) The Year 2000 problem: An observer's guide. International Journal of Information Management 19(3):195-205

Lisch R, Kriz J (1978) Grundlagen und Modelle der Inhaltsanalyse - Bestandsaufnahme und Kritik. Rowohlt, Reinbek

Mayer RC, Davis JH, Schoorman FD (1995) An integrative model of organizational trust. Academy of Management Review 20(3):709-734

Mayring P (2003) Qualitative Inhaltsanalyse Grundlagen und Techniken, 8th edn. Beltz, Weinheim

Mertens P (1995) Wirtschaftsinformatik - Von den Moden zum Trend. In: König W (ed) WIRTSCHAFTSINFORMATIK' 95 , Wettbewerbsfähigkeit - Innovation - Wirtschaftlichkeit. Physica, Heidelberg, pp 25-64

Mertens P (2002) Business Intelligence - Ein Überblick. Information Management \& Consulting 17(Sonderausgabe):65-73

Mertens P (2006a) Moden und Nachhaltigkeit in der Wirtschaftsinformatik. HMD - Praxis der Wirtschaftsinformatik 43(250):109-118

Mertens P (2006b) Moden und Nachhaltigkeit in der Wirtschaftsinformatik. Arbeitspapier Nr. 1, Universität Erlangen-Nürnberg

Mertens P, Barbian D (1999) Zur Situation der universitären Wirtschaftsinformatik in Deutschland. WIRTSCHAFTISINFORMATIK 41(6):565566
Mingers J (2003) The paucity of multimethod research: A review of the information systems literature. Information Systems Journal 13(3):233-249

Niederman F, Brancheau JC, Wetherbe JC (1991) Information systems management issues for the 1990 s. MIS Quarterly 15(4):475-500

Palvia PC, Mao E, Salam AF, Soliman KS (2003) Management information systems research: What's there in a methodology? Communications of the AIS 11:289-309

Palvia PC, Rajogopalan B, Kumar A, Kumar N (1996) Key information systems issues: An analysis of MIS publications. Information processing and management 32(3):345-355

Rautenstrauch C (1999) Anmerkungen zu "Von Leitbildern, Moden und Langfristzielen der Wirtschaftsinformatik" von Prof. Dr. Arno Rolf. WIRTSCHAFTSINFORMATIK 41(2):187

Riedl R, Rückel D, Roithmayr F (2008) On the evolution of research methods in information systems from 1968 to 2006: A meta-review. Working Paper. Institut für Wirtschaftsinformatik Information Engineering, Johannes Kepler Universität Linz

Robey D (1996) Research commentary: Diversity in information systems research: Threat, promise, and responsibility. Information Systems Research 7(4):400-408

Rotter JB (1967) A new scale for the measurement of interpersonal trust. Journal of Personality 35(4):651-655

Schauer C, Frank U (2007) Wirtschaftsinformatik und Information Systems - ein Vergleich aus wissenschaftlicher Sicht. In: Lehner F, Zelewski $S$ (eds) Wissenschaftstheoretische Fundierung und wissenschaftliche Orientierung der Wirtschaftsinformatik. GITO, Berlin, pp 122-155

Schauer C, Schauer H (2008) Die Wirtschaftsinformatik im Spannungsfeld zwischen Vielfalt und Profilbildung: Auf der Suche nach Kernkompetenzen einer vielfältigen Disziplin. In: Bichler M, Hess T, Krcmar H, Lechner U, Matthes F, Picot A, Speitkamp B, Wolf P (eds) Multikonferenz Wirtschaftsinformatik 2008 (MKWI). GITO, Berlin, pp 1521-1538

Sidorova A, Evangelopulos N, Valacich JS, Ramakrishnan T (2008) Uncovering the intellectual core of the information systems discipline. MIS Quarterly 32(3):467-482

Steininger K, Riedl R (2009) Ein Klassifikationsschema für Begriffe der Wirtschaftsinformatik und Information Systems. Forschungsbericht 09.02, Institute für Wirtschaftsinformatik an der Johannes Kepler Universität Linz, 2009

Straub DW (1989) Validating instruments in MIS research. MIS Quarterly 13(2):147-169

Strickland LH (1958) Surveillance and trust. Journal of Personality 26(2):200-215

Suarez FF, Lanzolla G (2008) The role of environmental dynamics in building a first mover advantage theory. Academy of Management Review 32(2):377-392

Sutter M, Kocher MG (2007) Trust and trustworthiness across different age groups. Games and Economic Behavior 59(2):364-382

Swanson EB, Ramiller NC (1993) Information systems research thematics: submissions to a new journal, 1987-1992. Information Systems Research 4(4):299-30

Vessey I, Ramesh V, Glass RL (2002) Research in information systems: An empirical study of diversity in the discipline and its journals. Journal of Management Information Systems 19(2):129-174

Wilde T, Hess T (2007) Forschungsmethoden der Wirtschaftsinformatik - Eine empirische Untersuchung. WIRTSCHAFTSINFORMATIK 49(4):280-287

WKWI (1994) Profil der Wirtschaftsinformatik. WIRTSCHAFTSINFORMATIK 36(1):80-81

Wohlgenannt R (1969) Was ist Wissenschaft? Vieweg, Braunschweig

Zak PJ, Knack S (2001) Trust and growth. Economic Journal 111(470):295-321

Zand DE (1972) Trust and managerial problem solving. Administrative Science Quarterly 17(2):229-339 